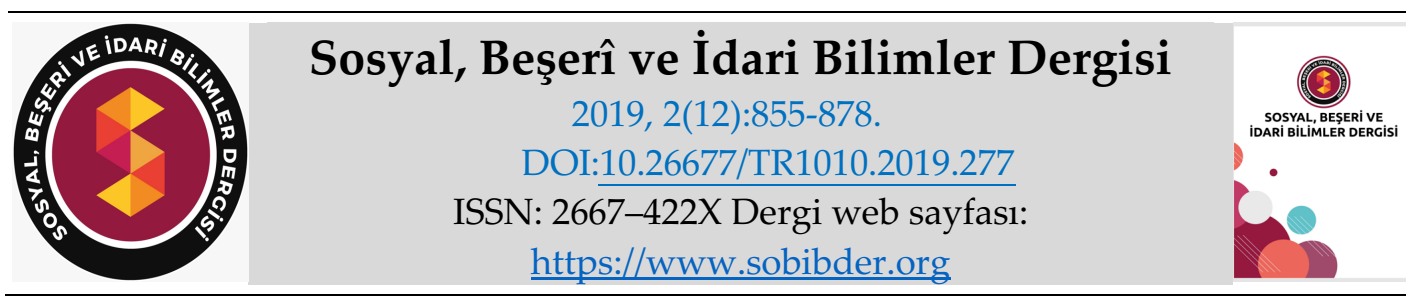

ARAȘTIRMA MAKALESI

\title{
Akhisar (Manisa) İlçesindeki Kırsal Yerleşim Birimlerinin Adlandırılmasında Etkili Olan Coğrafi Faktörler
}

Özcan AKINLI, Erzurum Valiliği, Özel Kalem Müdürlüğü, Açık Kapı Koordinatörlüğü, Erzurum, e-posta: 45ozcanakinli@gmail.com

ORCID: https://orcid.org/0000-0001-6426-6316

Dr. Öğr. Üyesi Ferdi AKBAŞ, Osmaniye Korkut Ata Üniversitesi, Kadirli Sosyal ve Beşeri Bilimler Fakültesi, Osmaniye, e-posta: ferdi.akbas45@gmail.com

ORCID: https://orcid.org/0000-0003-1899-1458

Öz

Adbilimin bir alt dalı olan yeradıbilimi ya da diğer adıyla toponiminin amacı belirli yöntemlerle yerlerin özel adlarını incelemek ve ad verme geleneğini ortaya çıkarmaktır. Toponimi, araştırmacıların hayli dikkatini çeken bir alan olmasına rağmen, bu alanda yapılan çalışmalarda farklı farklı yöntemlerin kullanılması bu çalışmaların belirli bir sistematiğe oturmadığını göstermektedir. Toponimi ve bu alanda yapılan sistemli çalışmalar dilciler kadar diğer alanlara özellikle de tarih araştırmacılarına katkı sağlamaktadır. Yerleşim birimlerinin adları göç yollarının tespitine ışı tutabilmekte, etnonim kaynaklı yeradları etnik yapıyı inceleyen bir tarih araştırmacısına yol gösterebilmektedir. Günümüzde halk dilinde kullanılmayan, unutulmuș kelimeler yeradlarında yaşamaktadır. Bir tepe, bir dere, bir pınar kim bilir adı ile geçmişten, bu topraklarda yaşamış atalarımızdan bizlere neler anlatmak ister. Anadolu coğrafyasındaki dil zenginliklerini ortaya koymak ve ecdadımızın kullandığı kelimeleri yeniden gün yüzüne çıkarmak yeradı çalışmalarında en önemli misyon olmalıdır. Çünkü gün geçtikçe unutulan ve unutulmaya yüz tutan bu adlar ne kadar çabuk tespit edilir ve kayıt altına alınırsa geçmiş ile olan bağımız o kadar sağlam olacaktır. Akhisar (Manisa) ilçesindeki kırsal yerleşim birimlerinin adlandırılmasında etkili olan faktörler adlı bu çalışma Akhisar ilçesi sınırları dahilinde yer alan kırsal yerleşimlerin adlandırılmasında etkili olan fiziki ve beşeri coğrafya faktörlerinin ortaya çıkarılması üzerine yapılmış bir araştırmadır. Çalışmanın amacını, ilçedeki kırsal yerleşim adlarının tespiti, tespit edilen bu yeradlarının yöreden edinilen bilgiler ile bugüne kadar yeradları konusunda yapılmış çalışmalardan da faydalanılarak araştırılması ve Akhisar yöresindeki yeradı verme geleneğinin ortaya çıkartılması oluşturmaktadır.

Anahtar Kelimeler: Toponimi, Yerleşim Birimleri, Manisa, Akhisar, Fiziki ve Beşeri Faktörler.

Makale Gönderme Tarihi: 25.08.2019

Makale Kabul Tarihi: 14.12.2019

\section{Önerilen Atıf:}

Akınlı, Ö. ve Akbaş, F. (2019). Akhisar (Manisa) İlçesindeki Kırsal Yerleşim Birimlerinin Adlandırılmasında Etkili Olan Coğrafi Faktörler, Sosyal, Beşeri ve İdari Bilimler Dergisi, 2(12): 855-878.

(C) 2019 Sosyal, Beşerî ve İdari Bilimler Dergisi.

\footnotetext{
* Bu çalışma Özcan Akınlı tarafından 2014 yılında tamamlanan yüksek lisans tezinden üretilmiştir.
} 


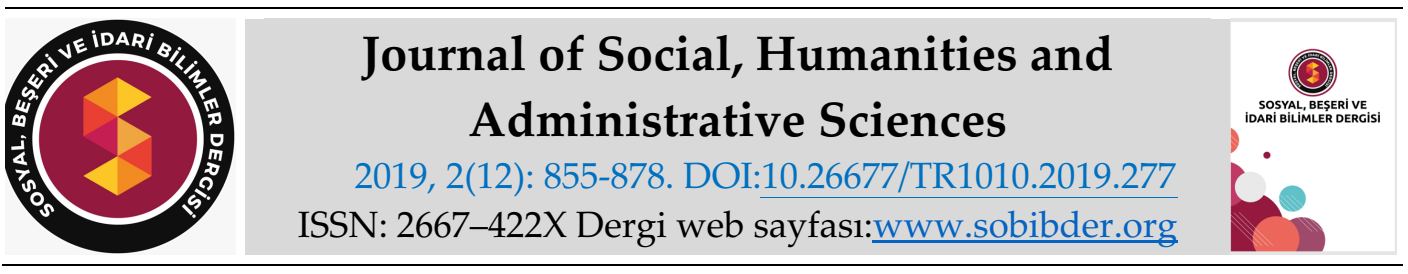

\title{
RESEARCH PAPER
}

\section{Geographical Factors that are Influential in Naming Rural Settlements in Akhisar (Manisa) District}

\author{
Özcan AKINLI, Governorship of Erzurum, Open Door Coordinator, Erzurum, e-mail: \\ 45ozcanakinli@gmail.com \\ ORCID: https://orcid.org/0000-0001-6426-6316
}

Assistant Professor Dr. Ferdi AKBAŞ, Osmaniye Korkut Ata University, Kadirli Faculty of Social Sciences and Humanities, Osmaniye, e-mail: ferdi.akbas45@gmail.com

ORCID: https://orcid.org/0000-0003-1899-1458

\begin{abstract}
The aim of the course is to examine the specific names of places and to reveal the tradition of naming them. Although toponymy is an area that has attracted the attention of researchers, the use of different methods in studies in this area shows that these studies do not fit into a particular Systematics. Toponymy and systematic studies in this field contribute to other fields, especially historical researchers as well as linguists. The names of the settlements can shed light on the identification of migration routes, and the ethnonymderived yerads can lead a history researcher who studies ethnic structure. Today, forgotten words that are not used colloquially live in their place. A hill, a stream, a spring who knows what our ancestors who lived in this land would like to tell us. To reveal the richness of language in Anatolian geography and to bring the words used by our ancestors back to the surface should be the most important mission in the work of yeradi. The sooner these names are identified and recorded, the stronger our connection to the past will be. Akhisar Akhisar (Manisa) rural settlements in the name of the factors that are effective in the naming of this study is a research on the determination of physical and Human Geography factors that are effective in the naming of rural settlements within the boundaries of Akhisar district. The purpose of the study is to determine the names of rural settlements in the district, to investigate these places by using the information obtained from the region and the studies made on the land names so far and to uncover the tradition of giving the place names in the region of Akhisar.
\end{abstract}

Keywords: Toponymy, Settlements, Manisa, Akhisar, Physical snd Human Factors.

Received: 25.08 .2019

Accepted: 14.12.2019

\section{Suggested Citation:}

Akınlı, Ö. and Akbaş, F. (2019). Geographical Factors that are Influential in Naming Rural Settlements in Akhisar (Manisa) District, Journal of Social, Humanities and Administrative Sciences, 2(12): 855-878.

(C) 2019 Sosyal, Beşerî ve İdari Bilimler Dergisi. 


\section{Gíriş}

Yer adlarının, bir yerin coğrafi, tarihi ve genel karakterini tanıma ve tanıtmada rolü büyüktür. Yer adları üzerinde tarih, coğrafya, sosyal gruplar ve kültürün etkisi önemli rol oynamaktadır. Gerek yerleşmenin tarihi gelişimi, gerekse coğrafi çevrenin eski durumu hakkında bilgi edinilebilen bir kaynak olması dolayısıyla, köy ve şehir isimleri üzerinde durulması faydalıdır (Göney, 1975: 274; Koday, 1998: 221-253).

İnsanlar yaşadıkları mekanı adlandırırken birtakım özelliklerden etkilenmektedir. Bu etkilenme fiziki ortamın herhangi bir niteliğinden ya da niceliğinden olabileceği gibi beşeri çevreden de kaynaklanabilmektedir. Kırsal yerleşimlere (eski adıyla köy, yeni adıyla mahalle) ad verilirken esas itibariyle iki temel husus üzerinde yoğunlaşılmaktadır (Koday ve Akbaş, 2016: 307-314). Bunlardan ilkini tıpkı Fındıklı ve Arhavi ilçelerinde olduğu gibi yerleşmelerin yakın çevrelerinde yer alan dă̆, tepe, akarsu, göl, bitki örtüsü, toprak türü gibi fiziki coğrafya ögeleri teşkil ederken, ikinci grup ise insan ve insan faaliyetleri, boy, kabile, aşiret, meslek adları, önemli olaylar gibi beşeri coğrafya özelliklerinden meydana gelmektedir (Tunçel, 2000: 24-27; Yaşar ve Yaşar, 2010: 599; Koday, 2003: 79; Koday, 2014: 108-109).

Yeradları, geçmiş dönemlerdeki nüfus hareketleri ile yerleşim tarihleri hakkında önemli bilgi kaynağıdır. Yerleşme adlarından hareketle Türk boy, aile, oymak, kabile ve soy özellikleri ile nerelerde hakimiyet kurdukları ve iskan ettikleri yörelerin coğrafi özelliklerinin nasıl olduğu hakkında bilgi edinilebilmektedir. Tüm bunlara ek olarak Osmanlı Devleti'nin son döneminde kaybedilen yerlerden Anadolu'ya olan göçler hakkında detaylı bilgi sahibi olunabilir ve böylece ilgili dönemdeki nüfus hareketli hakkında doğru ve yerinde çıkarımlar yapılabilir. Bu da ilgili coğrafi mekanın yerleşme tarihinin gün yüzüne çıkarılması bakımından büyük önem taşımaktadır (Yaşar ve Yaşar, 2010: 600; Koday ve Aydın, 2016: 448-459).

Coğrafi adlar, kabile, kavim, boy, nesil, göç gibi durumlardan izler taşımaktadır (Hüseynova, 2011: 1). Coğrafya yalnız bugüne değil, bir ucundan sıkı bir surette tarihi gelişmeye de bağlıdır. Arazinin, ovaların oldukça eski zamanda işleniş tarzı, gelişmenin dayanağı olan özellikler, tarih boyunca yerleşmeler, nüfusu, şehirlerin ortaya çıkışı, yaşaması ve bunları etkileyen coğrafi faktörlerin, eski durumun, tarihi gelişimin de bilinmesi ilmi niteliğin açıklık kazanmasında önemli faktördür (Karaboran, 1984: 97).

$\mathrm{Bu}$ çalışma Akhisar ilçesindeki kırsal yerleşim alanlarının adlandırılmasında etkili olan etkenlerin analizini kapsamaktadır. Çalışmada Akhisar Zeynelzâde Halk Kütüphanesi, Manisa Halk Kütüphanesi, Türk Tarih Kurumu, Afyonkarahisar Gedik Ahmet Paşa Halk Kütüphanesi ve Afyon Kocatepe Üniversitesi kütüphanelerinden istifade edilmiştir.

Toplanan yazılı kaynakların incelenmesi aşamasından sonra bütün köy muhtarlarıyla görüşülerek muhtarlardan yöredeki yeradları ile ilgili bilgi alınmıştır. Daha sonra köylerin tamamına yakını gezilerek yöre halkından bilgiler edinilmiştir. Bunun yanında yörenin yerel tarihini araştıran, köy köy dolaşıp derlemeler yapmış ve çevreyi iyi tanıyan yerel tarih araştırmacısı öğretmen Mustafa Kuzucuk'un bilgilerinden de istifade edilmiştir.

$\mathrm{Bu}$ araştırma Akhisar İlçesinin idari sınırları içerisinde yer alan 95 kırsal yerleşme ile sınırlandırılmıştır. Ancak haritada bulunan ve bugün adbilimin toponimi gibi bir alt dalı olarak kabul edilen urbonimi ya da Türkçe adıyla kentlikadbilim kapsamında ele alınabilecek, kente ait unsurlar olan ağıl, ahır, dam, değirmen, durak, ev, istasyon, kale, köprü, kente bağlı mahalle, mandıra, mezarlık, şehitlik, türbe adları tezin kapsamı dışında tutulmuştur. Çalışmamızın 95 kırsal yeradını içermesi nedeniyle yeradları mümkün olduğunca özet şeklinde değerlendirilmiştir. 


\section{AKHISSAR İLÇESİNIN GENEL COĞRAFİ ÖZELLÍKLERİ}

Aras,tırmanın konusunu olus,turan Akhisar Büyükşehir ilçesi Ege Bölgesi'nin Asıl Ege Bölümü sınırları içerisinde yer almaktadır. İdari bakımdan Manisa İlinin yönetim sınırları dahilinde olup, ilçe idari alanı içerisinde 1 ilçe merkezi, 95 kırsal mahalle bulunmaktadır. Sahanın sınırları belirlenirken idari faktör esas alınmıștır (Koday, Akbaş ve Kaya, 2017: 443-450). Buna göre; güneyde Manisa Gölmarmara, güneybatıda Saruhanlı, batıda İzmir Aliağa ilçesi, kuzeyde Balıkesir ili idari sınırları içerisinde kalan Sındırgı, kuzeybatıda Kırkağaç ve Soma, doğuda Gördes ilçeleri ile komşudur (Harita 1).

İdari açıdan Manisa iline bağlı olan ilçe, $1754 \mathrm{~km}^{2}$ lik geniş ve verimli bir ovanın ortasında, Gördük Çayı'nın kollarıyla birleştiği bir alanda, kuzey-güney ve doğu-batı yönündeki yolların birleştiği bir kavşak noktasında yer almaktadır (Karakuyu, 2012: 12). İlçenin güneyinde Gölmarmara, batısında Saruhanlı, kuzeyinde Kırkağaç, Soma ve Sındırgı ilçeleri ile Balıkesir ili yer almaktadır (Karakuyu vd., 2012: 21).

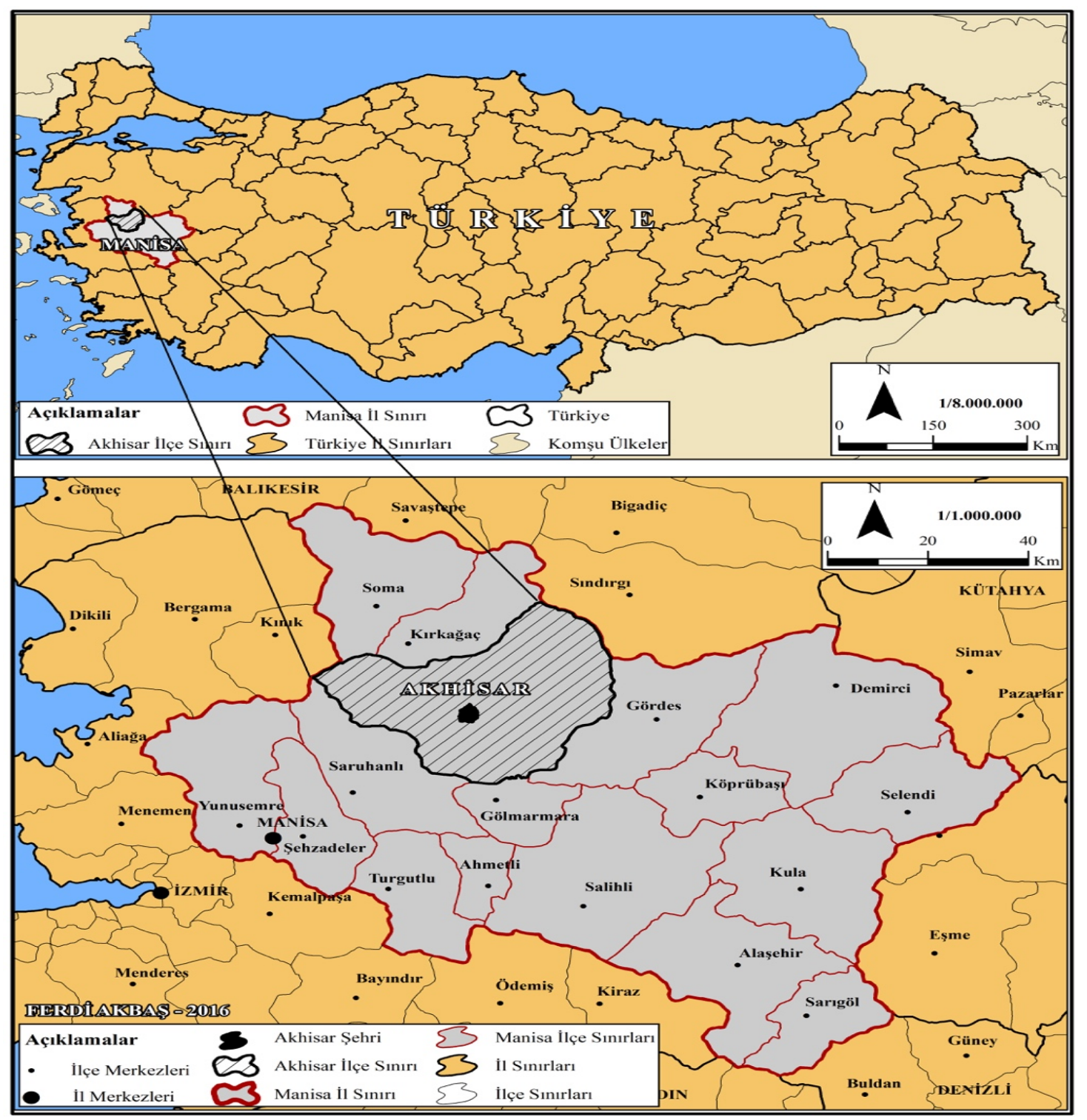

Harita 1. Akhisar İlçesi'nin Lokasyon Haritası 
Akhisar ilçesi iklim koşulları bakımından Akdeniz İklim Tipinin özelliklerini yansıtmaktadır. Ancak gerek kıyıdan biraz içeride yer almasından gerekse kuzeyindeki yüksek alanların etkisinden dolayı Akdeniz iklim tipinden bazı farklılıklar göstermektedir. Bunun yanında ilçe genelinde hem alanın genis, olmasından hem de yükselti farklarından kaynaklanan, alanları geniş olmayan iklim adaları bulunmaktadır (Karakuyu, Sarıusta, Yalçın, 2012: 42). Yükselti faktörünün etkin bir rol oynadığı sahada, yıllık ortalama sıcaklıklar $16,2{ }^{\circ} \mathrm{C}$ ve yıllık yağış miktarı $575,5 \mathrm{~mm}$. olarak belirmektedir. Araştırma sahasının bugünkü rölyef özelliklerini kazanmasında akarsular önemli bir role sahiptir. Suları, Kumçayı vasıtasıyla Gediz'e dolayısıyla Ege Denizi'ne boşaltılan inceleme sahasında büyüklü küçüklü çok sayıda akarsu bulunmaktadır. Bu akarsuların nispeten en önemlileri, Kumçayı, Gördük Çayı başta olmak üzere, Gökçay, Delice Çay, Kale dere ve Ilıcak Çayıdır (Hoşgören, 1983: 63). Akhisar'ın bitki örtüsü ana hatlarıyla iklim şartlarının etkisi altında șekillenmiştir (Arınc, 2011: 208). Akdeniz iklim özelliklerinin etkin oldugu sahada, bitki örtüsü de buna uygun olarak gelişme göstermiştir. Doğal vejetasyonun bozulmadığı sahada, başta kızılçam, yükseklere doğru da karaçamlardan oluşan orman topluluklarına rastlanmaktadır. Akdeniz ikliminin karakteristiği olan maki vejetasyonu da alüvyal ovalar ile yamaçlar arasında uzanan ormanlar arasında yayılış göstermektedir (Temuçin, 1991: 3). İlçe arazisindeki toprak örtüsünün oluşmasında iklim ve topografya gibi fiziki coğrafya faktörleri etkili olmuştur. Akhisar İlçesi'nde zonal, azonal ve intrazonal toprak grupları yayılış göstermektedir. İlçede en geniş yayılış alanına sahip topraklar, Kırmızı Akdeniz toprakları ile alüvyal topraklardır (Hoşgören, 1983: 4). Akdeniz ikliminin hakim olması yörede kırmızı Akdeniz topraklarının geniş bir yayılıs,a sahip olmasını saglamıs,tır. Maki örtüsü altında geliş,me gösteren bu toprakların yayılıs, alanları metamorfik gnayslar, diyaklazlı kalkerler ve kısmen de Neojen depoları üzerindedir (Arınc, 2011: 206). Akhisar ekonomisinin temelini tarım, hayvancılık, tarıma ve hammaddeye dayalı sanayi ile ticaret oluşturmaktadır. Fiziki ve beşeri coğrafya faktörleri, ilçedeki ekonomik faaliyetlerin oluşması ve gelişmesinde etkin bir rol oynamıştır. Akhisar ilçesinin topraklarının \% 47'si tarım arazi olarak kullanılırken, \% 40'1 orman alanı, \% 10'u yerleşim alanı ve \% 3'ü de çayır ve mera alanı olarak değrlendirilmektedir. İlçe, genel itibariyle ova üzerinde yer aldığı için tarım alanlarının oranı fazla olmakla birlikte bu tarım alanlarından elde edilen verim de oldukça yüksektir (Karakuyu, Sarıusta, Yalçın, 2012: 184; Koday, Akbaş ve Kaya, 2017: 443-455).

Çok eski bir yerleşim yeri olan Akhisar ve çevresinde, ilk insan izlerine Neolitik Çağ'da yani M.Ö. 7. bin yılda rastlanmıştır (Akdeniz ve Şahin, 2014: 1). M.Ö. 547 yılında İran'da yönetimi ele geçiren Perslerin Lidya ile yaptıkları savaşlar sonucunda Lidya Devleti yıkılarak Batı Anadolu ve aynı zamanda Akhisar, M.Ö. 500'lü yıllarda Pers egemenliği altına girmiştir. 100-150 yıl kadar Pers hâkimiyetinde kalan şehir İskender'in Anadolu Seferi ile İskender'in hâkimiyetine girmiştir (Ayaz, 2006: 8-9).

Bir süre Bergama Krallığı egemenliğinde olan şehir, M.Ö. 80 yılında Roma İmparatorluğu hâkimiyetine girmiş ve önemli bir merkez haline gelmiştir. Ancak Roma İmparatorluğunun Doğu ve Batı Roma olarak ikiye ayrılmasından sonra Doğu Roma olarak bilinen Bizans İmparatorluğu hâkimiyetine giren şehir asıl şöhretine ulaşmıştır (Ayaz, 2006: 9).

1300 yılından beri Manisa bölgesinde faaliyet gösteren Saruhanoğulları tarafından Türk hâkimiyetine alınan şehir, 1390'da Yıldırım Bayezid tarafından Osmanlı topraklarına katılmıştır (Emecen, 2007: 241). 1402 yılında yapılan Ankara Savaşı sonrasında gerek Timur istilası sonucu gerekse Aydınoğulları ile yapılan mücadeleler sonucu birkaç kez el değiştiren Akhisar, kesin olarak II. Murat döneminde Osmanlı hâkimiyetine girmiştir (Ayaz, 2006: 11).

Kurtuluş Savaşı döneminde Akhisar 1920-1922 yılları arasında Yunan işgali altında kalmıştır (Ayaz, 2006: 33). İki yıl boyunca Yunanlılar tarafından yağmalanan şehir 6 Eylül 1922'de Yunan işgalinden kurtulmuştur. 
Bu çalışmada Akhisar ilçesine bağlı kırsal yerleşmelerin adlandırılmasında etkisi bulunan coğrafi faktörler açıklanmaya çalışılmıştır. Çalışmanın amacı, Akhisar ilçesindeki kırsal birimlerin adlandırılmasında etkili olan faktörlerin ortaya çıarılmasıdır. Araştırmamızda gezi-gözlem, anket, mülakat ve doküman analizi yöntemleri kullanılmıştır. Kırsal yerleşimler, adlandırılmalarında etkili olan coğrafi faktörlere göre gruplandırılmıştır. Kırsal yerleşmelerin mevcut statüleri 6360 Sayılı Büyükşehir Yasası ile değiştirilmiştir. Bu kanunun yürürlüğe girmesiyle büyükşehir konumuna yükselen illerdeki köy ve kasaba gibi kırsal birimlerin tamamı bağlı bulundukları ilçenin mahallesi olmuştur. Bu kanunla birlikte köy ve kasabaların sahip oldukları fiziki ve beşeri coğrafya özelliklerinde herhangi bir değişiklik olmamıştır. Yerleşmelerin yalnızca idari durumları değişikliğe uğramıştır. Özetle, coğrafyacılar tarafından yapılan tüm çalışmalarda belirtildiği gibi köy ve kasabaların coğrafi olarak mevcut durumları korunmakta olup yapılan değişikler söz konusu yerleşim birimlerinin çeşitli hizmetlerden daha fazla faydalanabilmesini sağlamak amacıyla yapılmıştır.

\section{ARAŞTIRMA SAHASINDAKI KIRSAL YERLEŞIMLERIN TOPONOMİSI}

Çalışma evrenini teşkil eden Akhisar ilçesi'ndeki toplam kırsal yerleşme sayısı 95'tir (Tablo 1). Bu yerleşmelerin \%22,2'si fiziki coğrafya, \%74,6'sı beşerî coğrafya özelliklerinden adlarını almış olup, \%3,2'sinin ise adlarının kaynağına ulaşılamamıştır. Araştırma sahası kapsamındaki kırsal yerleşmelerin adlarının kaynakları ve bunların toplam oranı Tablo 1'de verilmiştir. Bunların yanında kırsal yerleşim birimlerin her birinin adlarının kaynağı ile ilgili elde edilen tüm veriler ilgili kategori altında detaylı bir şekilde açıklanmaya çalışılmıştır.

Tablo 1. Yerleşme Adlarının Kaynağını Oluşturan Unsurların Dağılışı

\begin{tabular}{|l|c|c|}
\hline Yerleşme Adlarının Kategorik Dağılımı & Yerleşme Sayısı & \%'si \\
\hline Adlarını Tarihi Olaylardan Alan Yerleşmeler & 11 & 11,6 \\
\hline $\begin{array}{l}\text { Adlarını Meslek Grupları, Ekonomik Faaliyetler ve Bu Faaliyetlerin } \\
\text { Sürdürüldüğ̈ Alanlardan Alan Yerleşmeler }\end{array}$ & 7 & 7,4 \\
\hline $\begin{array}{l}\text { Adını Tarih Öncesi Yerleşimler ile Tarihi Kalıntılardan Alan } \\
\text { Yerleşmeler }\end{array}$ & 1 & 1,1 \\
\hline $\begin{array}{l}\text { Adlarını Köyün Kurulduğu Yerde Daha Önce Bulunan Geçici ve } \\
\text { Devamlı Kırsal Yerleşimlerden Alan Yerleşmeler }\end{array}$ & 3 & 3,2 \\
\hline Adlarını Ulaşımla İlgili Unsurlardan Alan Yerleşmeler & 2 & 2,1 \\
\hline Adlarını Çeşitli Eşya ve Aletlerden Alan Yerleşmeler & 2 & 2,1 \\
\hline $\begin{array}{l}\text { Adlarını Boy, Aşiret, Cemaat, Kişiler ile Bunlara Ait Unsurlardan } \\
\text { Alan Yerleşmeler }\end{array}$ & 40 & 42,1 \\
\hline Adlarını Göç Hareketlerinden Alan Yerleşmeler & 5 & 5,3 \\
\hline Adlarını Litolojik Özelliklerden Alan Yerleşmeler & 7 & 4,2 \\
\hline Adlarını Bitki Örtüsünden ve Kültür Bitkilerinden Alan Yerleşmeler & 3 & 7,4 \\
\hline Adlarını Topografik Unsurlardan Alan Yerleşmeler & 7 & 3,2 \\
\hline Adlarını Higrografik Unsurlardan Alan Yerleşmeler & 3 & 3,4 \\
\hline Adının Kaynağı Tespit Edilemeyen Yerleşmeler & $\mathbf{9 5}$ & $\mathbf{1 0 0 , 0}$ \\
\hline Toplam & 3,2 \\
\hline
\end{tabular}




\section{ADLARINI LITTOLOJİK ÖZELLİKLERDEN ALAN YERLEŞMELER}

Araştırma sahasında bu kategoriye giren yerleşme sayısı 4 olup, bunlar Doğankaya, Kayganlı, Pekmezci ve Arabacıbozköy'dür. Çalışma sahasını etrafının yüksek kütlerle çevrili olması yerleşim birimlerinin adlandırılmasında etkili olmuştur. Söz konusu kategoriye dahil olan yerleşim birimleri toplam değer içerisinde $\% 4,2^{\prime}$ lik bir paya sahiptir. Yerleşim birimleri hakkında sahada yapılan çalışmalar sonucunda elde edilen bilgiler aşağıda detaylı bir şekilde açıklanmıştır.

Doğankaya Köyü: Yöre halkından alınan bilgiye göre köy, ilk olarak arkasında uzanan Görenez Dağı'nın eteklerinde kurulmuştur. Bu nedenle köy, bu dağdan dolayı ilk olarak Görenez adını almıştır. Ancak burada sık sık eşkıyaların soygunlarına uğradıkları için köy halkı köyün şimdiki yerine taşınmıştır. Yöre halkı; köyün önünüde yer alan, doğanların yuva yaptığı ve yörede Doğankaya adıyla bilinen kaya kitlesinden köyün günümüzdeki adını aldığını ifade etmektedir. Köy, Aydın Vilâyet Sâlnâmesi'nde (R.1307/H.1308) Körük nahiyesine bağlı Körenez karyesi adıyla geçmektedir (Câvid, 2010: 448).

Kayganlı Köyü: Osmanlı dönemi arşiv belgelerinde Kayukânlı (Kayukânlu) adıyla Sivas sancağında Ekrâd taifesinden bir oymak bulunmaktadır (Türkay, 1979: 33). Ancak bu oymağın ötesinde yöreden alınan bilgiye göre köyün bulunduğu alanda moloz taşların çok olması ve moloz taşların yapısı itibariyle kaygan olması sebebiyle köye "kaygan taşların çok olduğu yer" manasında Kayganlı adı verilmiştir.

Pekmezci Köyü: Osmanlı dönemi arşiv belgelerinde Pekmezli (Pekmezlü) adıyla Biga, Ankara, Teke, Hamîd, Menteşe, Aydın ve Karahisâr-ı Sâhib sancaklarında Türkmân tâifesinden bir cemaat bulunmaktadır (Türkay, 1979: 626). Ancak bu cemaatin ötesinde yöre halkı, köyün alt tarafında yer alan toprağın yörede pekmez yapımında kullanıldığını, pekmez toprağı olarak bilinen bu toprağın köy civarında çok olması nedeniyle "pekmez yapanlar" anlamında köye Pekmezci adının verildiğini ifade etmektedir.

Arabacıbozköy: Osmanlı dönemi arşiv belgelerinde Arabacı adıyla Paşa sancağı Edirne kazâsında Yörükân taifesinden bir cemaat bulunmaktadır (Türkay, 1979: 204). Ancak bu cemaatin dışında Başbakanlık Osmanlı Arşivleri 16.yüzyıl tahrir defterlerinde, Tapu-Kadastro Kuyûd-1 Kadîme Arşivi tahrir defterlerinde ve 166 Numaralı Muhâsebe-i Vilâyet-i Anadolu Defteri'nde (937/1530) köy, Palamud nahiyesine bağlı Bozköy adı ile geçmektedir (Emecen, 2013: 186), (Özkılınç vd, 1995: 307). Ayrıca Gökçen de (1946: 94-95) Sancaklı Aşireti ve Karayağcl Aşireti'nin bir kısmının Palamut nahiyesine bağlı Arabacıbozköy'e yerleştikleri belirtilmektedir. Köyün adı ile ilgili olarak yöre halkı ve Mustafa Kuzucuk, köyün arazisinin boz renkli bir toprak yapısına sahip olması nedeniyle köyün adının Bozköy olduğunu söylemektedir. Kuzucuk ve yöre halkı il merkezi Manisa'dan önce ilk çift tekerlekli at arabasının bu köyde yapılması nedeniyle Bozköy adına Arabacı eklendiğini ifade etmektedir.

\section{ADLARINI TOPOGRAFIK UNSURLARDAN ALAN KÖYLER}

Araştırma sahasında topografik özellikler yerleşim birimlerinin adlandırılmasında etkili olan önemli kaynaklardandır. Bu grupta toplamda 3 yerleşme bulunmakta olup, bunlar Çoruk, Sakarkaya ile Sirtköydür.

Çoruk Köyü: Yöre halkı ve Mustafa Kuzucuk'tan alınan bilgiye göre köy, Karatekeli Aşireti yörükleri tarafından kurulmuştur. Köyün kurulduğu yerin su ve bitki örtüsü bakımından yetersiz olması nedeniyle köye Çorak adı verilmiş, bu isim zamanla Çoruk olarak değişmiştir.

Sakarkaya Köyü: Yöre halkından ve Mustafa Kuzucuk'tan alınan bilgiye göre köy, Manisa Yuntdağı'nın uzantılarından olan Sakarkaya Dağı'nın eteğinde kurulması nedeniyle adını bu 
dağdan almıştır. Köy, Başbakanlık Osmanlı Arşivleri 16.yüzyıl tahrir defterlerinde, TapuKadastro Kuyûd-1 Kadîme Arşivi tahrir defterlerinde ve 166 Numaralı Muhâsebe-i Vilâyet-i Anadolu Defteri'nde (937/1530) Palamud nahiyesine bağlı görülmektedir (Emecen, 2013: 198; Özkılınç vd. , 1995: 309). Yine aynı tarihi kayıtlarda Dündarlu adlı bir mezranın da Sakarkaya köyüne bağlı olduğu görülmektedir (Emecen, 2013: 198; Özkılınç vd., 1995: 309).

Sırtköy: Yöreden alınan bilgiye göre köy, yaklaşık 150-200 yılllık bir geçmişe sahip olup dağın sırtında yer alması nedeniyle Sırtköy adını almıştır.

\section{ADLARINI BİTKI ÖRTÜSÜNDEN VE KÜLTÜR BİTKILERINDEN ALAN KÖYLER}

İnsanlar yerleşim birimlerini adlandırırken o yerin sahip olduğu bitki örtüsünden faydalanmışlardır. Araştırma sahasında Kadıdağı, Çal Dağı, Görenez Dağı gibi yüksek kütlelerin bulunması insanlara ikamet ettikleri yerleşimleri adlandırmaları konusunda ilham kaynağı olmuştur. Akhisar'da adını bitki örtüsünden alan köy sayısı 7 (\% 7,4)'dir. Bu yerleşmeler Çamönü, Selvili, Kavakalan, Sarıçalı, Sazoba, Söğütlü ve Zeytinliovadır. Bu yerleşmelerin adları hakkındaki detaylı bilgiler aşağıda verilmiştir.

Çamönü: Yöre halkından edinilen bilgiye göre köyün eski adı Karasonya olup Cumhuriyet döneminden önce köy nüfusunun çoğunu Rumlar oluşturmakta ve Sonya adının da Rumca olduğu yöre halkınca ifade edilmektedir. Yakın tarihte köyün adı değiştirilerek Çamönü olmuştur. Yöreden alınan bilgiye göre köyün kurulduğu yerin arkasındaki dağın çam ağaçları bakımından zengin olması, çamlık olması nedeniyle köye Çamönü adı verilmiştir.

Selvili: Yöreden ve Mustafa Kuzucuk'tan alınan bilgiye göre köy halkının ilk yerleşim yeri Saruhanlı ilçesinin Boğazhan Mevkisi olup zamanla bu mevkinin hayvancılık yapmak için elverişli olmaması nedeniyle köy halkı bugünkü yerleşim yerine göç etmiştir. Köy halkı, köyün arazisini Kırkağaç'a bağlı Bakır kasabasında yaşayan iki kardeşten satın almış ve buraya yerleşmiştir. Köy, 1951 yılına kadar Çobanhasan köyüne bağlı Selvili adıyla bir mahalle iken 1951'de bağımsız bir köy haline gelmiştir (Resmî Gazete, 2 Ocak 1951: 325). Köyün bulunduğu alanda selvi ağaçlarının çok olması sebebiyle köye Selvili adının verildiği yöre halkınca ifade edilmektedir.

Kavakalan: Köy, Aydın Vilâyet Sâlnâmesi'nde (R.1307/H.1308) Kayacık nahiyesine bağlı Kavakalan karyesi adıyla geçmektedir (Câvid, 2010: 440). Yöre halkından alınan bilgiye göre köy halkı eski dönemlerde köyün bulunduğu alana yerleşmeden önce ilk olarak Som Alanı adlı alana yerleşmişlerdir. Daha sonraki dönemlerde köyün bulunduğu alana Som Alanı, İnbaşı ve Kulfalı yerleşim yerlerinden gelen halk köyü meydana getirmiştir. Oğuzların Üçok Boyu'na mensup olduklarını ifade eden yöre halkı, kuruluşu döneminde köyün bulunduğu alanda kavak ağaçlarının çok olması nedeniyle köye Kavakhaalan adının verildiğini, sonraları bu adın Kavakalan'a dönüştüğünü ifade etmektedir.

Sarıçalı: Osmanlı dönemi arşiv belgelerinde Sıracalı adıyla Aydın sancağı ile Saruhan sancağı Mağnisa kazâsında bir aşiret bulunmaktadır (Türkay, 1979: 129). Ancak bu aşiretin ötesinde yöre halkından alınan bilgiye göre köy, geçmişte şimdiki yerinin üst kısmındaki çalılarla kaplı tepede kurulmuş ve çalıların yoğun olduğu bu köye Sarıçalı adı verilmiştir.

Sazoba: Osmanlı dönemi arşiv belgelerinde Sazoba adıyla Saruhan sancağı Akhisar kazâsı'nda Yörükân taifesinden bir cemaat bulunmaktadır (Türkay, 1979: 664). Ancak bu cemaatin dışında Kuzucuk, köy yakınından geçen Kumçayı kenarındaki sazlık araziden köyün adını aldığını, köyün önceki adının Sazlıoba olduğunu ifade etmektedir. Köy, Aydın Vilâyet Sâlnâmesi'nde (R.1307/H.1308) Gölmarmaracık nahiyesine bağlı Saz karyesi adıyla geçmektedir (Câvid, 2010: 449). Başbakanlık Osmanlı Arşivleri 16.yüzyıl tahrir defterlerinde ve Tapu-Kadastro Kuyûd-1 
Kadîme Arşivi tahrir defterlerinde de köy, Palamud nahiyesine bağlı Saz adı ile geçmektedir (Emecen, 2013: 200).

Söğütlü: Osmanlı dönemi arşiv belgelerinde Söğüd, Söğüdlü (Söğüdlüoğullarl) adlarıyla Kütahya, Meraş, Hamîdeli, Karahisâr-1 Şarkî, Biga, Canik, Hudâvendigâr, Karasi, Ankara sancakları ve Diyarbekir eyâletinde konar-göçer Yörükân taifesinden bir cemaat bulunmaktadır (Türkay, 1979: 682). Yine 16. yüzyıl tapu tahrir defterinde Söğ̈̈dlü adıyla Beğdili Boyu'na mensup olarak Biga sancağında bir cemaat bulunmaktadır (Halaçoğlu, 2011: 2048). Ancak bu cemaatlerin dişında yöreden alınan bilgiye göre köyün güneyinden geçen Akhisar-Sındırgi-Simav yolunun alt tarafındaki çay yatağında eskiden söğüt ve çınar ağaçlarının çok olması nedeniyle köy Söğütlü adını almıştır.

Zeytinliova: Yöreden ve Akhisar belediyesi kayıtlarından edinilen bilgiye göre kasabanın güneyinde dağılmakta olan Palamut adlı köyün adı yeni kurulan bu yerleşim yerine verilmiş ve köyün ilk adı Palamut olmuştur. Sonraki dönemlerde Yağköy olan köyün adı zamanla Yayaköy'e dönüşmüştür. Yörede zeytin ağacının çok olması nedeniyle 1960'lı yıllarda köye Zeytinliova adı verilmiştir.

\section{ADLARINI HIDROGRAFIK ÖZELLİKLERDEN ALAN YERLEŞMELER}

Tarih boyunca ilk medeniyetler su kaynaklarının yakınında kurulmuşlardır (Yaşar ve Yaşar, 2010: 604). Bundan dolayı su yerleşmeler için hem hayat kaynağı hem de çekim merkezi olmuştur. İnsanlar gerek geçmişte gerekse günümüzde daima su kaynaklarına yakın mekanları iskan alanı seçmişlerdir. Araştırma alanının sınırları dahilinde yer alan yerleşmelerin adlandırılmasında hidrografik faktörler esin kaynağı olmuşlardır. İnceleme alanında 7 yerleşmenin adı hidrografik kaynaklara dayanmaktadır. Bunlar, Akçeşme, Dereköy, Pınarcık, Sarnıçköy, Ulupınar, Dağdere ve Medar'dır.

Akçeşme: Yöre halkından edinilen bilgiye göre köy adını, köyün içinde yer alan suyu bol, beyaz badanalı bir çeşmeden almıştır.

Dereköy: Osmanlı dönemi arşiv belgelerinde Dereköy adıyla Niğde sancağında Türkmân Yörükânı tâifesinden bir cemaat bulunmaktadır (Türkay, 1979: 321). Ancak bu cemaatin ötesinde yöre halkından alınan bilgiye göre köy, adını köyün girişinde ve çıkışındaki derelerden almıştır. Köyün iki tarafında da derenin yer alması nedeniyle köye Dereköy adı verilmiştir (Câvid, 2010: 434).

Pınarcık: Yöre halkı, köyün 1927 yılına kadar Kennes adıyla bir Rum köyü olduğunu 1927 yılında Türklerin yaşadığı bir köy haline geldiğini ve 1974 yılına kadar Kennes olarak kalan köyün adının 1974'te Pınarcık olarak değiştirildiğini ifade etmektedir. Köy, Pınarcık adını köy civarında su kaynaklarının bol olması, pınarların çokluğu nedeniyle almıştır.

Sarnıçköy: Osmanlı dönemi arşiv belgelerinde Sarnıclı (Sarnıclu) adıyla Aydın ve Karahisâr-ı Şarkî sancaklarında Yörükân taifesinden bir cemaat bulunmaktadır (Türkay, 1979: 651). Ancak yöre halkı ve Mustafa Kuzucuk bu cemaatin ötesinde, köyün bulunduğu alanın kayalık bir yapıda olması nedeniyle yağmur ve kar sularının kayalık alandaki çukurlarda birikerek doğal sarnıçların oluşmasına neden olduğunu, köyün çevresinde de oldukça fazla olan bu doğal kaya sarnıçları nedeniyle köye Sarnıç adının verildiğini ifade etmektedir.

Ulupınar: Yöre halkından alınan bilgiye göre köy, yakınında yer alan Ulupınar adındaki büyük bir çeşmeden adını almıştır. 
Dağdere: 16. yüzyıl tapu tahrir defterleri ve Başbakanlık Osmanlı Arşivleri tahrir defterlerinde Dağdere adıyla, Beğdili Boyu'na mensup olarak Atçeken Yörükleri taifesinden Niğde, Ankara, Konya sancakları ile Karaman vilayetinde bir cemaat bulunmaktadır (Halaçoğlu, 2011: 579-580). Ancak yöreden alınan bilgiye göre kasabanın kuruluş yeri itibariyle bir dağ eteğinde olması ve kasabayı ikiye ayıran, kasabanın ortasından geçen bir derenin yer alması nedeniyle kasaba Dağdere adını almıştır (Câvid, 2010: 440).

Medar: Yöreden edinilen bilgiye göre yöre halkı, ilk olarak eski bir yerleşim yeri olan Örentepe mevkisine yerleşmiştir. Sonraki bir dönemde rivayete göre Menteşoğlu adlı bir ailenin gelininin hastalanıp kasabanın günümüzde bulunduğu alandan akan sudan içmesi ve burada dinlenip şifa bulması hadisesi sonucunda bu alana yedi ailenin gelerek yerleşmesi ve bu yerleşim yerine "medet, yardımcı" anlamında Medar adının verilmesi ile köy meydana gelmiştir. Medar adını alan köy, 1973 yılında belediyelik olunca bir dönem Ovaköy adını almış ancak daha sonra tekrar Medar adı verilmiştir (Câvid, 2010: 448).

\section{ADLARINI TARİHI OLAYLARDAN ALAN YERLEŞMELER}

Tarih boyunca yaşanan olaylar yerleşim yerlerinin adlandırılmasında etkili olmuştur. Meydana gelen bu olayların insanlar üzerinde oluşturduğu etki coğrafi mekanlara ad verilirken onların içdünyalarının da yansımasını sağlamıştır. Akhisar ilçesindeki kırsal yerleşmelerden Akçaalan, Başlamış, Evkaftepe, Hanpaşa, Kadıdağı, Kızlaralanı, Kurtulmuş, Muştullar, Selçikli, Şehitler ve Akselendi yerleşimleri adlarını taraih boyunca meydana gelen olaylardan almışlardır.

Akçaalan: Akçaalan adı ile ilgili olarak araştırmacı Mustafa Kuzucuk, yöre halkınca iki rivayet anlatıldığını dile getirmektedir. Kuzucuk, ilk rivayete göre; eski dönemlerde bölge köylerinden vergi toplamakla görevli memurların bir ay süre ile bu köyde kaldıklarını bu nedenle köyün adının "akçe alınan yer" manasında Akçealan olduğunu, ikinci rivayete göre ise; eski tarihlerde bu köy yakınlarında bazı değerli madenlerin çıkarıldığını bu madenlerde günlük ücretle çalışan işçilerin yevmiyelerinin (akçelerinin) bu bölgede ödendiğini ve akçelerini (ücretlerini) alan işçilerin kaldıkları mekanı ifade etmek için "akçe alanlar" sözünün kullanıldığını, bu sözün zamanla Akçaalan şekline dönüştügüüü ifade etmektedir. Gökçen (1950: 50), köyün Gördes'ten gelen Meşeli ve Taşdibi Yörükleri tarafından kurulduğunu ifade etmektedir.

Başlamış: Yöre halkınca köyün adının anlamı ile ilgili iki farklı bilgi verilmiştir. Bunlardan ilki, Osmanlı İmparatorluğu döneminde şehzadeler şehri Manisa sancağından saray merkezi İstanbul'a gitmekte olan önemli bir kafile bugünkü Başlamış köyü yakınlarına gelmiş ve kafileden hamile olan bir hatunun doğum sancıları başlamıştır. Doğum sancılarının bu köy yakınında başlaması nedeniyle köye Başlamış adı verilmiştir. İkinci rivayet ise eski dönemlerde camisi olmayan bu köy ve civar köylerden birine cami yapılması kararı alındığını duyan köylüler arasında caminin hangi köye yapılacağı konusunda münakaşa çıması ve münakaşanın bu köyde başlaması nedeniyle köye "münakaşanın başladığı yer" anlamında Başlamış adının verildiğidir. Yerel tarih araştırmacısı Mustafa Kuzucuk ise bu iki rivayetten farklı olarak, tarihî kayıtlarda Saruhan sancağına bağlı 36 köyü olan Gördük nahiyesinin nâhiye merkezinin Başlamış köyü olduğunu bu nedenle "nâhiyenin başlangıcı" anlamında köye Başlamış adının verildiğini ifade etmektedir. Yöre halkınca anlatılan ilk rivayetin bu köy ile birlikte yakınındaki diğer iki köyün adına da kaynaklık etmesi nedeniyle köyün adını bu olaydan aldığg düşünülmektedir.

Evkafteke: Yöre halkının ve Mustafa Kuzucuk'un verdiği bilgiye göre köy, 1800'lü yıllarda İzmir tarafından gelen Çalık Bey adlı Yörük beyinin obası ile köyün bulunduğu alana gelip yerleşmesi sonucu kurulmuştur. Köyün ilk adı, kurucusundan dolayı Çalık Bey Obası'dır. Yöre halkı, eski dönemlerde yoksullara yapılacak yardımların bu köyde toplanıp vakfedilmesi nedeniyle köyün 
adının Evkaftekke olarak değiştiğini ifade etmektedir. Zamanla da Evkaftekke adı Evkafteke olarak değişmiştir. Köyün adının 1950'li yıllarda da Evkaftekke olarak geçtiği görülmektedir (Gökçen, 1950: 55).

Hanpaşa: Yörede köyün adı ile ilgili olarak bir rivayetten bahsedilmektedir. Rivayete göre eski dönemlerde Manisa Paşaköy'de oturan dönemin paşasının köyün şimdiki yerinden 5-6 km. aşağısında yer alan hana gelip konakladığı ve hancının beslediği avcı şahini alıp şahin ile keklik yakaladığı, hancının bir gün avlanmak için gelen paşaya şahini vermek istememesi nedeniyle paşa ile hancı arasında tartışma yaşanması sonucu hancının paşayı öldürdüğü bu nedenle "hanın da paşalığın da hancıya kaldığı" manasında köyün Hanpaşa adını aldığı yöre halkınca ifade edilmektedir.

Kadıdağı: Yöre halkından alınan bilgiye göre köyün arkasında uzanan Kadıdağı adlı büyük dağda, sık ormanların içinde eski dönemlerde bir kadı efendinin kaybolması nedeniyle dağ bu hadiseden dolayı Kadıdağı adını almıştır. Kadıdağı köyü ise adını köyün arkasında uzanan Kadıdă̆ğ'ndan almıştır.

Kızlaralanı: Yöre halkı, eski dönemlerde köyün yukarı mahallesinde tepe üstündeki alanda hıdırellez, nevruz ve bayram gibi önemli günleri kutlamak için kadınların ve kızların toplandığını ve çeşitli oyunlar oynadığını, bu kutlamaları ve kalabalı̆̆ı köy yakınından gelip geçerken görenlerin bu köye Kızlarınalanı adını verdiğini zamanla bu adın Kızlaralanı şekline dönüştüğünü ifade etmektedir.

Kurtulmuş: Yöre halkı, Osmanlı İmparatorluğu döneminde Manisa sancağından saray merkezi İstanbul'a gitmekte olan bir kafilenin Başlamış köyü yakınlarına geldiklerinde kafilede hamile olan önemli bir hatunun doğum sancılarının başladığını, Başlamış köyü ile aynı güzergâhta ve yakınında olan Kurtulmuş köyü civarına geldiklerinde de doğum hadisesinin gerçekleştiğini bu nedenle "doğum yapıp kurtuldu manasında doğumun olduğu bu köye Kurtulmuş adının verildiğini ifade etmektedir.

Muştullar: Yöre halkı, Osmanlı İmparatorluğu döneminde Manisa sancağından saray merkezi İstanbul'a gitmekte olan bir kafilenin Başlamış köyü yakınlarına geldiklerinde kafilede hamile olan önemli bir hatunun doğum sancılarının başladığını, Başlamış köyü ile aynı güzergâhta ve yakınında olan Kurtulmuş köyü civarına geldiklerinde doğum hadisesinin gerçekleştiğini ve bu doğum hadisesini de Muştullar köyü halkının müjdelemesi neticesinde köye "müjde edenler, muştulayanlar" manasında Muştullar adının verildiğini ifade etmektedir.

Selçikli: Osmanlı dönemi arşiv belgelerinde Selçik, Selçikler, Selçikli (Selçiklü) adlarıyla Tarsus, Hudâvendigâr ve Kütahya sancaklarında Türkmân taifesinden bir cemaat bulunmaktadır (Türkay, 1979: 666). Ancak bu cemaatin ötesinde yöre halkından alınan bilgiye göre Toplar Mevkisi adıyla bilinen tepe, köy halkının ilk yerleşim yeri olup Yunan işgali yıllarında köylülerin hayvanlarının elinden alınması ve köydeki erkeklerin orduya katılması nedeniyle köyde kalan yaşlı, kadın ve çocuklar düşmandan saklanmak amacıyla burayı terkederek, iki küçük tepe arasında, uzaktan bakıldığında görünmeyen, köyün şimdiki bulunduğu alanda saklanmışlardır. Bu nedenle köy ilk olarak "saklanılan yer" anlamında Sincekli adını almış ve bu ad zamanla Selçikli'ye dönüşmüştür.

Şehitler: Araştırmacı Mustafa Kuzucuk ve yöre halkı Eceler (Ecirler) adlı bu köy yakınında 1920 yılında Yunanlılar tarafından 11 kişinin toplu olarak şehit edilmesi nedeniyle 11 şehidin anısına köye Şehitler adının verildiğini ifade etmektedir.

Akselendi: Günümüzde köyün güneyinden geçen Kumçayı'nın yatağının eski dönemlerde bu yerleşim yerinin kenarından geçmesi ve Kumçayı'nın yatağından taşması sonucu köyün bulunduğu alan sular altında kalmış ve bu nedenle köye Selindi adı verilmiştir. Zamanla Selendi 
adını alan köy 1960 yılında belediyelik olmuş ve Manisa'nın Selendi ilçesinden ayırtetmek için Akselendi adı verilmiştir.

\section{ADLARINI TARİH ÖNCESİ YERLEŞİMLER İLE TARİHİ KALINTILARDAN ALAN YERLEŞMELER}

Araştırma sahasında bu kategoride yalnızca bir kırsal yerleşim birimi bulunmaktadır. Büknüş adını taşıyan bu yerleşme hakkında detaylı bilgiler sahada yapılan mülakatlar neticesinde elde edilmiştir.

Büknüş: Yöre halkı Büknüş adı ile ilgili olarak, köyün bulunduğu alanda kalıntılarının günümüze kadar ulaştığı Bizans döneminde Bük adlı bir şehrin olduğunu, sonraki dönemlerde bu şehrin olduğu yere yörük taifesinden Gümüş adlı bir çobanın gelip yerleştiğini, o dönemde eski Bük şehri ve Gümüş adlı çobanın adından esinlenerek köye Bükmüş adının verildiğini ve adın zamanla Büknüş olarak değiştiğini ifade etmektedir.

\section{ADLARINI MESLEK GRUPLARI, EKONOMIK FAALIYETLER VE BU FAALIYYETLERİN SÜRDÜRÜLDÜĞÜ ALANLARDAN ALAN YERLEŞMELER}

Araştırma alanında bu grup altında toplam 7 yerleşme bulunmktadır. Toplam oran içerisinde \% 7,4'lük bir orana sahip olan bu yerleşmeler Boyalılar, Çanakçı, Kapaklı, Kömürcü, Sağrakçı, Tütenli ve Zeytinlibağ' dır.

Boyalılar: Mustafa Kuzucuk'tan ve yöreden alınan bilgiye göre köy halkının eski dönemlerde halı ve kilim dokumada kullanılan ipleri boyamada mahir olmaları nedeniyle köye Boyalılar adı verilmiştir.

Çanakçı: Yöre halkının eski dönemlerde köyün yakınındaki derede yer alan çınar ağaçlarından ahşap mutfak kapları, tabak ve çanaklar yapmaları neticesinde "çanak yapanlar" manasında köye Çanakçı adı verilmiştir.

Kapaklı: Yöreden edinilen bilgiye göre eski dönemlerde içme suyunun temini noktasında büyük önem arz eden su kuyularının ağzına kapak yapımının devrim niteliğinde bir hadise olması nedeniyle Akhisar ve çevresinde ilk olarak kuyu kapakları bu köyde yapılmış ve köy Kapaklı olarak adlandırılmıştır.

Kömürcü: Yöre halkından alınan bilgiye göre ısınmak için mangalın kullanıldığı dönemlerde köy halkının meşe odunlarını yakıp mangal kömürü elde ettikten sonra Akhisar'a gidip esnafa mangal kömürü satarak geçimlerini kömürcülükle sağladıkları için köye Kömürcü adı verilmiştir.

Sağrakçı: Köyün adıyla ilgili olarak yöre halkından alınan bilgiye göre eski dönemlerde, yörede ağacı oyarak tas, bardak, çanak gibi malzeme yapımı ile uğraşılması ve bu malzemelere de yörede sağrak adının verilmesi nedeniyle köye "sağrak yapanlar" manasında Sağrakçı adı verilmiştir. Sağrak, Derleme Sözlüğü'nde "ağaçtan yapılmış yağ kabı" anlamında, Tarama Sözlüğü'nde de "kadeh, bardak, sürahi, maşrapa, tas" anlamlarındadır (DS, 1978: 3514).

Tütenli: Yöreden ve Kuzucuk'tan alınan bilgiye göre eski adı Milinge olan köy, eskiden Rum halkının yerleşim yeridir. Rumca olan Milinge adı, köyde tütün yetiştiriciliğinin meşhur olması nedeniyle kaymakamlık kararıyla Tütenli olarak değiştirilmiştir.

Zeytinlibağ: Yöreden alınan bilgiye göre köy, 1992 yılına kadar Çanakçı köyüne bağlı Değirmenbaşı adında bir mahalle iken 1992'de Çanakçı köyünden Zeytinlibağ köyü adı ile 
ayrılmıştır. Köy, Zeytinlibağ adını köy halkının zeytincilikle yoğun bir şekilde uğraşması nedeniyle almıştır.

\section{ADLARINI KÖYÜN KURULDUĞU YERDE DAHA ÖNCE BULUNAN GEÇİCİ VE DEVAMLI KIRSAL YERLEŞIMLERDEN ALAN YERLEŞMELER}

Araştırma sahasında bu başlık altında toplam 3 yerleşme tespit edilmiştir. Bunlar; Bünyanosmaniye, Dayığlu ve Topluca'dır.

Bünyanosmaniye: Yöre halkı ve Kuzucuk'tan alınan bilgiye göre, köyün bulunduğu alan Osmanlı döneminde Demirci Çiftliği adlı bir Rum çiftliği iken tarihte 93 Harbi olarak bilinen 18771878 Osmanlı-Rus Savaşı sonrasında Mora Yarımadası'ndan göç ettirilen Osmanlı tebaası köyü meydana getirmiştir. Demirci Çiftliği'nin sahibi çiftliğin bulunduğu araziyi köy halkına köyün adının Demirci Çiftliği kalması şartıyla satmıştır. Uzun yıllar bu adı ile bilinen köye 1930'lu yıllarda devletçe, geçmişte Rumeli' deki Osmanlı idaresine bağlılığı nedeniyle "Osmanlı'nın şânı, Osmanlı yapısı" anlamında Bünyan-ı Osmaniye adı verilmiştir.

Dayığlu: Yöre halkından alınan bilgiye göre köy kurulmadan önce köyün olduğu yerde Dayıŏ̆lu Çiftliği adıyla bir çiftlik bulunmaktadır. Yöre halkı, çiftlik yakınlarına çiftlik sahibinin akrabalarının da yerleşmesi sonucu köyün kurulduğunu ifade etmektedir. Bu nedenle köy, adını eski dönemlerdeki Dayıoğlu Çiftliği'inden almıştır.

Topluca: Köy, Aydın Vilâyet Sâlnâmesi'nde (R.1307/H.1308) Akhisar kazâsına bağlı Berekle karyesi adıyla geçmektedir (Câvid, 2010: 448). 1928 tarihli Son Teşkilatı Mülkiyede Köylerimizin Adları isimli kaynakta köy, Bergele adıyla görülmektedir (Dâhiliye Vekâleti, 1928: 967). İçişleri Bakanlığı'na ait Köylerimiz adlı kaynakta da köyün eski adı Bergele olarak geçmektedir (İçişleri Bakanlığı, 1968: 516). Evliya Çelebi Seyahatnâmesi'nde de köy, Bergele adıyla geçmekte olup, 20 haneli, 1 camili ve bir âb-ı hayat kaynak sulu Müslüman köyü olarak tarif edilmektedir (Kahraman, 2011: 66). Yöre halk1 da köyün eski adının Bergele olduğunu, Kızıldamlar ve Gökbel olarak da anılan köyün, daha sonra Topluca adını aldı̆̆ını ifade etmektedir.

\section{ADLARINI ULAŞIMLA İLGİLI UNSURLARDAN ALAN YERLEŞMELER}

Araştırma sahasında bu başlık altında Seğirdim ve Yayakırıldık adlı iki kırsal yerleşme bulunmaktadır.

Seğirdim: Yöre halk1, Seğirdim kelimesini "koşmak, bir koşuşta varmak" anlamıyla bilmektedir. Yörükân taifesine mensup olan köy halkının eski dönemlerde bir yerde sabit kalmayıp sürekli oradan oraya koşuşturması nedeniyle köye bu adın verilmiş olabileceği yöre halkınca ifade edilmektedir. Akhisar ilçe merkezine uzaklığ 8 km olan köyden ilçeye kısa bir zamanda, hızlıca ulaşılabilinmesi nedeniyle "bir koşuşta alınan mesafe" anlamıyla köyün Seğirdim adını aldığını düşünülmektedir.

Yayakırıldık: Yöreden ve Kuzucuk'tan alınan bilgiye göre köyün Gördes Kayacık beldesi ile Akhisar yerleşim yerlerinin tam ortasında kalması nedeniyle eski dönemlerde her iki yerleşim yerine gidiş ve gelişlerde dinlenmek için bu köyde bir gece kalınıp sabah yola devam edilmekteymiş. Yolcuların çok yorulması ve bu köyde istirahat etmesi nedeniyle "yayalar kırıldı" ifadesi kullanılmış ve zamanla köyün adı Yayakırıldı olmuş, sonraki bir dönemde de Yayakırıldık olmuştur. 


\section{ADLARINI ÇEŞITTLİ EŞYA VE ALETLERDEN ALAN YERLEŞMELER}

Araştırma evrenini teşkil eden Akhisar'da kırsal yerleşimlerin adlandırılmasında çeşitli eşya ve aletler ilham kaynağı olmuştur. Bu kategoride değerlendirilecek köyler Dolmadeğirmen ile Karabörklü kırsal yerleşimleridir.

Dolmadeğirmen: Yöre halkı, eski dönemlerde Dolma Değirmen adıyla bilinen doldurma taşlarla yapılmış su ile çalışan değirmenin baz alınarak değirmenin yukarısında yer alan bu köye Yukarıdolma adı verildiğini söylemektedir. Değirmenin alt tarafında yer alan köye ise Aşağıdolma köyü adı verilmiştir.

Karabörklü: Yöreden alınan bilgiye göre eski dönemlerde köy halkının Börk adı verilen bir başlık giymeleri nedeniyle köye Karabörklü adı verilmiştir.

\section{ADLARINI GÖÇ HAREKETLERİNDEN ALAN YERLEŞMELER}

Göçler tarih boyunca yerleşim birimlerinin fiziki ve beşeri yapısında önemli değişiklikler meydna getirmiştir. Aynı zamanda tarihin bazı dönemlerinde yerleşmelerin adlandırılmasında insanlara esin kaynağı olmuştur. Araştırma alanında adlarını göç hareketleri neticesinde alan köy sayısı 5 olup bu değerin toplam oran içerisindeki payı \% 5,3'tür (Tablo 1). Söz konusu yerleşmeler, Doğuca, Göcek, Moralılar, Yeniceköy ve Yenidoğan'dır.

Doğuca: Yöre halkının verdiği bilgiye göre eski dönemlerde Yunanistan'ın Doğuca köyünden şimdiki köyün bulunduğu alana göçen köy halkı Yunanistan'daki köylerinin adını bu köye vermişlerdir.

Göcek: Yöre halkından alınan bilgiye göre Aydın tarafından gelen göçebe yörüklerin köyün bulunduğu alana gelip yerleşmesi sonucu köy meydana gelmiştir. Bu nedenle köye "göçebelik, göçerlik" manasında Göcek adı verilmiştir.

Moralılar: Yöreden ve Mustafa Kuzucuk'tan alınan bilgiye göre tarihte 93 Harbi olarak bilinen 1877-1878 Osmanlı-Rus Savaşı sonrasında Mora Yarımadası'ndan gelen muhacirler köyü meydana getirmiştir. Mora'dan gelen göçmen halkın yeni kurdukları bu yerleşim yerine göç ettikleri yeri ifade eden Moralılar adı verilmiştir.

Yeniceköy: Araştırmacı Mustafa Kuzucuk, köy halkının ilk olarak Doğankaya (Görenez) köyüne yerleştiğini, buradaki halk ile anlaşmazlıkların yaşanması nedeniyle Hancılar ve Mandam (yörede Mal Damları adıyla bilinir) mevkilerine yerleştiklerini daha sonraki bir dönemde Karasonya köyüne (Günümüzdeki adı Çamönü) bağlı, köyün şimdiki bulunduğu alanda yer alan Yeşilsonya mahallesine göç ettiklerini ve yeni bir yerleşim yeri kurulduğu için bu köye Yeniceköy adının verildiğini ifade etmektedir.

Yenidoğan: Yöreden ve Kuzucuk'tan alınan bilgiye göre köyün ilk kuruluş yeri Şahbaz Deresi'nin güney kesimidir. Köy halkı sonraki bir dönemde hayvancilığa elverişli olan köyün şimdiki bulunduğu alana yerleşmiştir. Şahbaz Deresi'nden köyün şimdiki bulunduğu alana yerleşen halk arasında Cezayir tarafından gelen Arap asıllı halkın da olması nedeniyle köye ilk olarak Araplar adı verilmiştir. 1992 yılına kadar Seğirdim köyüne bağlı bir mahalle iken 1992' de ayrılarak köy tüzel kişiliğini yeni kazanan bir yerleşim birimi olması nedeniyle köy muhtarı Osman Ceyhan tarafından köye Yenidoğan adı verilmiştir. 


\section{ADLARINI BOY, AŞİRET, CEMAAT, KİŞİLER İLE BUNLARA AİT UNSURLARDAN ALAN YERLEŞMELER}

Kırsal yerleşmeler adlarını göçebe hayatı sürdürürken bölgede yerleşik düzendeki boy, aşiret, cemaat ve kişilerden alabilmektedir (Koday, 2000: 236). Çalışma sahasında bu kategoride yer alan köy sayısı bir hayli fazladır. İlçe sınırları içerisinde bulunan toplam 95 kırsal yerleşmenin 40'1 adlarını boy, aşiret, cemaat, kişiler ile bunlara ait unsurlardan almaktadır. Bu grubun toplam oran içerisindeki değerinin \% 42,1'dir. Söz konusu köyleri hakkında edinilen bilgiler aşağıda yer almaktadir.

Akkocalı: Osmanlı dönemi arşiv belgelerinde Akkoca, Akkocalı (Akkocalu) adlarıyla Kütahya, Mağnisa, İçel, Adana, Tarsus, Sis, Hamîd sancaklarında Türkmân Yörükânı taifesinden bir cemaat bulunmaktadır (Türkay, 1979: 190). Ayrıca Karakuyu (2012: 38) ve Satış (1994: 319) iskan sırasında Akkocalı ve Musacalı aşiretlerinin Gördük bucağına yerleştirildiklerini belirtmiştir. Gökçen'in (1946: 94) çalışmasında yer alan Manisa Mahkeme-i Şer'iyye Sicil Defteri (M.1864-1874) kayıtlarında da Akkocalı Aşireti'nin Gördük kazâsı civarına yerleştikleri belirtilmektedir. Köyün adı da bu aşiretten gelmektedir.

Bekirler: Yöreden ve Kuzucuk'tan alınan bilgiye göre Lozan Mübadele Anlaşması (1923) sonucunda Yunanistan'ın Larissa kentinden göçürülen halk köyü oluşturmuştur. O dönemde köyün bulunduğu alanda Bekir Ağa adlı bir çiftlik sahibinin geniş arazisi yer almakta olup Yunanistan'dan göçürülen halka bu arazi verildiği için köy, adını çiftlik sahibi Bekir A $\breve{g} a^{\prime}$ dan almıştır.

Çıtak: Tarihi kayıtlarda Çatak, Çataklı, Çataklu adlarıyla bir cemaatin görülmesi ve Kayacık Kazâsının Avârız Defteri'nde de köyün Çatak adıyla geçmesi köy adının etnonim olduğunu göstermektedir.

Çobanhasan: Yöre halkı Karakeçili Yörükleri'nden çobanlık yapan Hasan adlı bir şahsın köyün bulunduğu alana gelerek burada çadır kurup, burayı yurt edinmesi sonucu köyün kurulduğunu ve köyün adını bu şahıstan aldığını ifade etmektedir.

Dingiller: Yöre halkı, Dingiloğulları lakabıyla bilinen yörükan taifesinden üç kardeşin köyün bulunduğu alana hayvancllık yapmak için gelerek buraya yerleştiğini, ormanlık ve havadar bir yer olan bu alana zamanla başka ailelerin de gelmesiyle köyün meydana geldiğini ifade etmektedir. Yöre halkı köyün adını Dingiloğulları olarak bilinen bu üç kardeşten aldığını ve zamanla Dingiller olarak değiştiğini dile getirmektedir.

Rahmiye: Yöre halkı, Sultan Abdülhâmid'in eski dönemlerde köy civarında bir çiftliğinin olduğunu ve Rahmiye ismindeki kızının bu çiftlikte vefat etmesi ve buraya defnedilmesi nedeniyle köyün Abdülhâmit' in kızı Rahmiye'nin adını aldığını söylemektedir.

Sünnetçiler: Mustafa Kuzucuk, eski dönemlerde köyün bulunduğu alandaki arazinin Yatağan köyü halkı tarafından kışlak olarak kullanıldığını, Yatağan köyü halkından Donsuz Ahmet adıyla bilinen şahsın kış bitiminde Yatağan köyüne dönmeyerek bu alanı yurt edindiğini ve zamanla Donsuz Ahmet'in çadırı etrafında yerleşen halkın Sünnetçiler köyünü meydana getirdiğini ifade etmektedir.

Beyoba: Yöre halkından ve Beyoba belediyesi kayıtlarından edinilen bilgiye göre Erzurum Horasan'dan gelen Kündeşli Aşireti mensupları sulak ve hayvancılık için otlağı bol olan beldenin bulunduğu alana gelerek çadırlarını kurup yerleşmiş ve bugünkü yerleşim yerini meydana getirmişlerdir. Bu alanı yurt edinen aşiretin ileri gelenleri Kınık ilçesi Beyoba köyünde oturan Bektaş Çelebi'yi yerleşmesi için bu bölgeye davet etmiş̧, bölgeye gelen Bektaş Çelebi “bey obası 
gibi yer" diyerek bu alana yerleşmiş ve yerleşim yerinin adı Bey obası olarak kalmıştır. Daha sonraki dönemlerde beldenin adı Beyoba olmuştur.

Durasıl: Yöre halkından ve Mustafa Kuzucuk'tan alınan bilgiye göre eski dönemlerde Ulupınar köyünde yaşayan Durasıl köyü halkının bir kısmı Ulupınar'dan ayrılarak Durasıllı Aşireti'nin çadırlarının yer aldığı, köyün günümüzdeki yerine gelip yerleşmiş ve bugünkü köyü oluşturmuştur. Köy halkının Durasıllı Aşireti'nin çadırlarının bulunduğu alana yerleşmesi nedeniyle köy, adını bu aşiretten almıştır.

Eroğlu: Yöreden ve Mustafa Kuzucuk'tan alınan bilgiye göre Sünnetçiler köyünden Erzâdeler Sülalesi'nden bir ailenin, köyün bulunduğu alana ilk olarak gelip yerleşmesi ve zamanla başka ailelerin de gelmesi sonucu köy meydana gelmiş ve köye, ilk yerleşen aile olan Erzâdeler'in adı verilmiştir.

Gökçeahmet: Yöreden alınan bilgiye göre Gök Ahmet adlı bir şahsın köyün bulunduğu alana gelip burayı yurt edinmesi ve zamanla başka ailelerin de buraya yerleşmesi sonucu köy, meydana gelmiştir. Köy, adını köyün bulunduğu alana ilk yerleşen Gök Ahmet adlı şahıstan almış olup Gök Ahmet adı zamanla Gökçeahmet olarak değişmiştir.

Gökçeler: Yöre halk1, eski dönemlerde Aydın yöresinden gelip köyün bulunduğu alana yerleşen halkın hayvancılıkla uğraşması ve keçi sürülerinin olması nedeniyle köye Gökkeçiler adı verildiğini daha sonra köyün adının Gökçeler olarak değiştiğini ifade etmektedir. Kanaatimizce yöre halkının anlattığı halk etimolojisinin ötesinde köy, Gökceler adlı cemaatten adını almıştır. Yöre halkının Aydın yöresinden gelen halkın bu alana yerleşerek köyü meydana getirdiğini ifade etmesi ve Gökceler adlı cemaatin de Aydın yöresinde yaşamış olması bu düşüncemizi desteklemektedir.

Hacıosmanlar: Yöreden alınan bilgiye göre geçmişte yörükân taifesinden Osman adlı bir şahsın ailesiyle birlikte köyün bulunduğu alana ilk olarak gelip yerleşmesi nedeniyle köy adını bu şahıstan almıştır.

Sabancılar: Yöre halkından köyün adının kaynağı ile ilgili net bir bilgi alınamamıştır. Yöre halkı eski dönemlerde köyde saban yapıldığı için köyün bu adı almış olabileceğini ifade etmektedir. Ancak kanaatimizce köyün adını Sabancılar adlı cemaatten alma olasılığı daha yüksektir.

Taşçılar: Yöreden ve Mustafa Kuzucuk'tan alınan bilgiye göre köyün batı kesiminde mezar yapımında kullanılan taşların çok olması ve eski dönemlerde mezartaşı yapımı işiyle uğraşan, Taşçıŏulları adlı bir sülalenin köyün bulunduğu alana ilk yerleşenler olması nedeniyle köy, bu sülaleden adını almıştır. Bu sülalenin mezarları günümüzde köy mezarlığında mevcuttur.

Kayalığlu: yöre halkından ve Kayalığlu Belediyesinden alınan bilgiye göre, kasaba çevresi eski dönemlerde burada kurulan Yahudi tarım okuluna ait bir arazidir. Yahudi tarım okulunun kapanmasıyla, bu okul arazisi satılarak Ahmet Kayalı adlı bir şahsın çiftliği olmuştur. Çiftlik sahibi Ahmet Kayalı'nın sonraki dönemlerde çiftlik topraklarını yöre halkına satması nedeniyle Saraçoğlu köyü olan köyün adı çiftlik sahibinden dolayı Kayahıŏ̆lu köyü olarak değişmiştir.

Hacıibrahimler: Yöreden alınan bilgiye göre geçmişte Hamit köyünün mahallesi olan köy, 1990 yılında köy tüzel kişiliğine kavuşmuştur. Geçmiş dönemde bu köy mahalle iken Hacı İbrahim adlı bir şahsın ailesiyle birlikte mahalleye ilk yerleşen kişi olması nedeniyle mahalle adını bu şahıstan almıştır.

Hamidiye: Yöre halkından alınan bilgiye göre köy, 100-120 yıllık bir geçmişe sahip olup geçmiş dönemlerde köyün olduğu yer Yahudi Çiftliği adıyla bilinen bir çiftliktir. Balkan Savaşı yıllarında Yunanistan'ın Selânik kentinden gelen göçmen nüfusun köyün bulunduğu alana yerleşmesiyle 
köy meydana gelmiştir. Yöre halkı, Balkan Savaşı göçmenlerinin buraya yerleştirilmesi nedeniyle Sultan II. Abdülhamid'e şükran ifadesi için köye Hamidiye adının verildiğini ifade etmektedir.

Hamitköy: 1646 yılında Osmanlı İmparatorluğunun Girit Seferi sırasında tanzim edilen Kayacık Kazâsının Avârız Defteri adlı vergi defterinde ise köy Kayacık kazâsına bağlı karye-i Hamid-oba adıyla geçmektedir (Emecen, 2007: 237). Bu bilgiler doğrultusunda köyün adının etnonim kaynaklı olduğu ortaya çıkmaktadır.

Harmandalı: Yöre halkından alınan bilgiye göre de Türkmân taifesinden Harmandalı Cemaati'nin bir kısmı köyün bulunduğu alana gelip burayı yurt edinmiş ve bu halk köyü meydana getirmiştir. Yaklaşık 250 yıllık bir geçmişe sahip olan köy, adını köy halkının mensubu olduğu Harmandalı Cemaati'nden almıştır.

Hasköy: Yöre halkı ve yerel tarih araştırmacısı Mustafa Kuzucuk'tan alınan bilgiye göre eski dönemlerde, konar-göçerlik yıllarında köy halkının Bursa ile Eskişehir arasındaki İğneci Yaylası'nı yazlak olarak kullanması nedeniyle köy halkına yörede İ̆̆neci Aşireti denilmektedir. Yöre halkınca köyün adının anlamı ve kaynağı bilinmemektedir. Ancak Emecen (2013: 275), Manisa kazâsındaki bir kısım köylerin Osmanlı toprak yönetim sistemine göre mîrî arazi olarak padişah, sancakbeyi ve şehzade hâslarına tahsîs olunduğunu ifade etmektedir. Ayrıca Nagata (1979: 756), Palamut ve Yengi nahiyelerinde bulunan padişahın hâs köylerinde pamuk ve kökboyası yetiştirildiğini belirtmektedir. Bu bilgiler doğrultusunda Hasköy'ün, Osmanlı İmparatorluğu döneminde sancakbeyi gibi devlet yönetiminde görevli kişilerin "hâs"larından bir köy olabileceğini ve köyün, "hâs arazi" olması nedeniyle Hasköy adını aldığı düşünülmektedir.

Sarılar: Yöre halkı ve Kuzucuk'un verdiği bilgiye göre de eski dönemlerde Sarllar Cemaati'nin köyün bulunduğu alana yerleşmesi ile köy meydana gelmiş ve köy, mensubu olduğu bu cemaatten adını almıştır.

Üçavlu: Köy, Başbakanlık Osmanlı Arşivleri 16.yüzyıl tahrir defterlerinde, Tapu-Kadastro Kuyûd-1 Kadîme Arşivi tahrir defterlerinde ve 166 Numaralı Muhâsebe-i Vilâyet-i Anadolu Defteri'nde (937/1530) Palamud nahiyesine bağlı Üç-Havlu adı ile geçmektedir (Emecen, 2013: 201; Özkılınç vd. , 1995: 309). Kuzucuk, havlu isminin Arapça havele (çevirdi) fiilinden türediğini ve havlu kelimesinin "etrafı çevrili, korunaklı yer" anlamında kullanıldığını ifade etmektedir. Kuzucuk, " $h$ " harfindeki mahreç zayıflığı nedeniyle Rumeli göçmenlerinin yaşadığı bu köyde " $\mathrm{h}$ " harflerinin söylenmediği ve bu nedenle tarihî kayıtlarda Üç-Havlu olarak geçen köyün adının zamanla Üçavlu olarak değiştiğini ifade etmektedir. Yöre halkı da üç çobanın köyün bulunduğu alana gelerek yerleşmesi sonucu köyün kurulduğunu ifade etmektedir.

Süleymanlı: Yöre halkından edinilen bilgiye göre Saruhanoğulları Beyliği sınırları içerisinde halkı Türk olan bir obanın beldenin 5 km. kuzeydoğusundaki Değirmenönü Mevkisi'nde yerleşik düzene geçmesiyle o zamanlar köy olan Süleymanlı köyü kurulmuştur. Değirmenönü Mevkisi'nde tarımla uğraşan yöre halkı, sel gibi doğal afetlerden korunmak için daha yüksekte yer alan Oban Mevkisi adıyla bilinen, eski adı Kâfir Hasan Çamlığı olan yere taşınmıştır. Ancak yeni yerleştikleri bu bölgenin toprak yapısı bakımından zararlı haşerâtın çoğalmasına, barınmasına elverişli olması ve haşerelerin halka zarar vermesi nedeniyle zamanın bilgin zâtlarından $\mathrm{Hacı}$ Süleyman Efendi'nin girişimi ve öncülügünde beldenin şimdiki bulunduğu alan yeni yerleşim yeri olarak seçilmiştir. Hacı Süleyman Efendi'nin etrafında saygı gören ve halka önderlik eden bir kişi olması nedeniyle beldenin adı Süleymanlı olarak benimsenmiştir. Ancak yöre halkınca anlatılan halk etimolojisinin ötesinde Süleymanlı adının etnonim kaynaklı olduğunu göstermektedir.

Işıkköy: Köy, Osmanlı dönemi arşiv belgelerinde Işık, Işıklar, Işıklı, Işıklılar adlarıyla İçel, Paşa, Tarsus, Adana, Gelibolu, Karasi, Karahisâr-1 Sâhib, Sis, Cânik, Hudâvendigâr, Niğbolu, Aydın, Teke, Biga, Çirmen, Kütahya ve Sığla sancaklarında Yörükân taifesinden bir cemaat 
bulunmaktadır (Türkay, 1979: 443-444). Yine 16. yüzyıl tahrir defterlerinde Işıklar adıyla, Eymür Boyu'na mensup olarak Saruhan sancağında bir cemaat bulunmaktadır (Halaçoğlu, 2011: 1083). Bu bilgiler yeradının etnonim kaynaklı olduğunu ifade etmektedir.

İsaca: Yöre halkından alınan bilgiye göre köyün bulunduğu alana ilk gelip yerleşen İsa adlı bir çoban olmuş daha sonra başka ailelerin de gelip buraya yerleşmesi sonucu köy meydana gelmiştir. Köy, adını köyün bulunduğu alana ilk gelip yerleşmiş olan İsa çobandan almıştır.

Karaköy: Yöre halkı Akhisar Karaköy yakınında çam ağaçları ile örtülü bir tepede Horasanlı Süleyman oğlu Karaca Ahmet adlı Horasan evliyâlarından bir zâtın medfun olduğunu ve Karaköy'ün adının bu velî kişiden geldiğini ifade etmektedir.

Karayağcı: Yöre halkı Karayă̆gı Cemaati'ne mensup olan köy halkının eski dönemlerde, günümüzde Gördes ilçesine bağlı Karayağcı köyünün bulunduğu alanı yazlak, Akhisar Karayağcl köyünün bulunduğu alanı da kışlak olarak kullandığını, daha sonraki dönemlerde kışın geldikleri Akhisar Karayağcı köyünün bulunduğu alana yerleşip burada kalarak köyü meydana getirdiklerini ifade etmektedir.

Kobaşdere: Yöre halkından da edinilen bilgiye göre köy, adını Kobaş Cemaati'nden almıştır. Yöre halkı, eski dönemde Kobaş Yörüklerinin köyün şimdiki bulunduğu alanın alt tarafındaki dere kenarına yerleştiklerini ve bu nedenle köyün adını bu cemaatten aldığını ifade etmektedir.

Sindelli: Yöre halkı eski dönemlerde Çökek köyünde Sindel Baba adlı bir evliyânın yaşaması nedeniyle köyün bu zâttan adını aldığını ifade etmektedir.

Yatağan: Yöreden ve Mustafa Kuzucuk'tan alınan bilgiye göre Anadolu'nun Türkleşmesi ve İslamlaşması sırasında Karapavli'ye gelen Horasan erenlerinden Yatağan Mahmut Sultan, Saruhan Beyliği'ne kuzeyden yapılan bir saldırıyı müridleriyle birlikte önlemiş ve bunun sonucunda Mahmut Sultan'a Saruhan Bey tarafından bir ferman ile Karapavli arazisi verilerek, Karapavli olan yerleşim yerinin adı Yatağan Mahmut Sultan olarak değiştirilmiştir. Yatağan Mahmut Sultan olan köyün adı zamanla Yatağan olarak kısaltılmıştır.

Ballıca: Yöre halkı, Sıdan Yaylası'ndan gelen yörükân taifesinden bir beyin, ailesiyle birlikte kasabanın bulunduğu alana gelip yerleşerek balın bol olduğu, sokaklara aktığı bu yeni yerleşim yerine "balı çok olan" manasında Ballıca adını verdiğini ifade etmektedir. Ancak anlatılan bu halk etimolojisinin ötesinde beldenin Ballı ya da Ballıca adlı cemaatten adını aldığını, Ballıca adının da etnonim kökenli olduğunu göstermektedir.

Kocakağan: Yöreden alınan bilgiye göre Osmanlı hâkimiyetinden önceki dönemlerde köyün bulunduğu alanda net olmamakla birlikte bir kağanın yaşadığı ifade edilmektedir. Köyün adının da bu kişiden geldiği belirtilmektedir.

Kulaksızlar: Yerel tarih araştırmacısı Mustafa Kuzucuk'tan ve yöreden alınan bilgiye göre köyün bulunduğu alana ilk gelip yerleşen şahsın kulaklarının başına oranla çok büyük olması nedeniyle, şahsın bu fiziki yapısıyla alay etmek için bu kişiye Kulaksız Dayı denilmiş dolayısıyla bu iskân yerine de Kulaksızlar adı verilmiştir.

Musalar: Yöre halkı köyü Musalar Cemaati'ne mensup halkın meydana getirdiğini, bu nedenle köyün bu cemaatten adını aldığını ifade etmektedir.

Musaca: Osmanlı dönemi arşiv belgelerinde Mûsâca adıyla Vize sancağı, Rakka, Erzurum, Kars ve Çıldır eyâletlerinde Yörükân taifesinden bir cemaat bulunmaktadır (Türkay, 1979: 594). Yine Osmanlı dönemi arşiv belgelerinde Mûsâcalı (Mûsâcalu) adıyla Hudâvendigâr, Kengıri, Sivas, Haleb, Rakka, Bozok, Aydın, Kayseriyye, Saruhan, Akşehir, Erzurum, Kars, Aksaray, Karahisâr1 Şarkî, Diyarbekir, Çıldır, Karaman, Şam, İçel, Adana, Karahisâr-1 Sâhib, Cânik, Niğde, Gelibolu 
ve Çirmen sancaklarında Türkmân taifesinden bir cemaat bulunmaktadır (Türkay, 1979: 594). Ayrıca Karakuyu (2012: 38) ve Satış (1994: 319) iskân sırasında Akkocalı ve Musacalı aşiretlerinin Gördük bucağına yerleştirildiklerini belirtmiştir. Dolayısıyla köyün adını bu aşiretlerden geldiği düşünülmektedir.

Süleymanköy: Osmanlı dönemi arşiv belgelerinde Süleymân, Süleymânlı (Süleymânlu), Süleymânlar adlarıyla Bozok, Meraş, Alâiye, Teke, Ankara, Rakka, Kengıri, Kırşehri, Karahisâr-1 Şarkî, Selânik, Karahisâr-1 Sâhib, Haleb, Malatya, Adana, Aksaray, Kütahya, Tarsus, Aydın sancaklarında Türkmân taifesinden bir cemaat bulunmaktadır (Türkay, 1979: 686). 16. yüzyıl tapu tahrir defterlerinde Süleymanlı adıyla, Kızık Boyu'na mensup olarak Mukataahâne Yörükleri taifesinden Saruhan sancağı Manisa kazâsı Palamud nahiyesi Balballar köyü yakınlarında bir cemaat bulunmaktadır (Halaçoğlu, 2011: 2071). Köy, Aydın Vilâyet Sâlnâmesi'nde (R.1307/H.1308) Palamut nahiyesine bağl1 276 nüfuslu Süleyman karyesi adıyla geçmektedir (Câvid, 2010: 435). Bu bilgiler köyün adının etnonim kaynaklı olduğunu göstermektedir.

Yeğenoba: Yöre halkı, köy meydana gelmeden önceki dönemlerde köye 5-6 km uzaklıkta olan Yanıkdağ Mevkisi'nde oturan bir ağanın suyu bol, hayvancılığa elverişli olan köyün şimdiki bulunduğu alanda yeğenine ev yaptırması ve ağanın yeğeninin oturduğu bu alana başka ailelerin de yerleşmesi sonucu köye "yeğenin obası" anlamında Yeğenoba adının verildiğini ifade etmektedir.

\section{ADLARININ KAYNAĞI TESPİT EDİLEMEYEN YERLEŞMELER}

Araştırma sahasında kırsal yerleşim birimlerinin adlarının kaynaklarinin tespit edilmesi amacıyla yapılan bu çalışmada 3 köyün adının kaynağı ve köylerle ilgili herhangi bir bilgiye ulaşılamamıştır. Köylülerle yapılan görüşmeler ve ilgili konu hakkındaki literatür taraması neticesinde Erdelli, Yaykın ve Mecidiye kırsal yerleşimleri hakkında bilgiye erişilememiştir.

\section{SONUÇ}

Yer adları hem yerleşim birimlerinin tarihi hem de coğrafi mekanın özellikleri hakkında bilgi vermesi nedeniyle büyük önem taşımaktadır. Yer adları bir milletin belleğini meydana getiren tarih, coğrafya, edebiyat gibi alanlar için hayati sembollerdir. Ülkemizde yeradları ile ilgili araştırmların yaygınlaşması geçmiş dönemlere ait sosyo-kültürel ve sosyo-ekonomik yapımızın ortaya çıkmasını sağlayacaktır.

Kırsal yerleşmelerin adlarını konu edinen araştırmalar söz konusu birimlerin hem tarihi hem coğrafi hem de dil ve edebiyat bakımından geçirdiği süreçleri gün yüzüne çıarmaktadır. Araştırma sahasını teşkil eden Akhisar ilçesinde hatırı sayılır bir değerde bir çok köy adını aşiret, cemaat ve kişilerden almıştır. Bu durum Akhisar'da kurulduğu günden bu yana sahip olduğu coğrafi konumun da etkisiyle nüfus hareketlerinin yoğun olarak yaşandığını ortaya koymaktadır. Ilçenin yerleşme tarihinin aydınlatılmasında ve nüfus yapısının kaynağı konusunda bilgi edinilmesini sağlayan yer adları adeta kaynak niteliği taşımaktadır. Son olarak yer adları insan ve coğrafi ortam arasındaki karşılıklı ilişki sonucunda ortaya çıkmıştır. Insanların yaşadıkları mekanı adlandırırken yakın çevrelerinde yer alan fiziki ve beşeri coğrafya ögelerinden esinlenmeleri tarih boyunca hep olmuştur bundan sonraki süreçte de devam edecektir.

\section{KAYNAKLAR}

Ada, E. (2012). Eskişehir İli Yer Adları, Yayınlanmamış Yüksek Lisans Tezi, Ege Üniversitesi, İzmir. Akalın, Ş. H. (1997). Akhisar'da Karaca Ahmet Türbesi ve Bu Türbe ile İlgili İnançlar. (Online) 
https://turkoloji.cu.edu.tr/kisisel/akalin/KARACA HTML [Erişim Tarihi: 03.07.2014]

Akdeniz, E. ve Şahin, M. K. (2014). Akhisar Gezi Rehberi. Akhisar: Akhisar Belediyesi Kültür Yayınları.

Alagöz, C. A. (1984). Türkiye'de Yer Adaları Üzerine Bazı Düşünceler, Türk Yer Adları Sempozyumu Bildirileri: (ss.11-23) 11-13 Eylül 1984-Ankara: Kültür ve Turizm Bakanlığı Yayınları.

Algın, Y. ve Bozacı, G. B. (1999). Akhisar'in Yerel Tarihi. Manisa: Emek Matbaacıllk.

Alkayış, M. F. (2007). Türkiye Türkçesinde Bitki Adları, Yayınlanmamış Doktora Tezi, Erciyes Üniversitesi, Kayseri.

Ayaz, B. (2006). Cumhuriyet'in Illk Yıllarında Akhisar Kazası (1923 - 1933). Yayınlanmamış Yüksek Lisans Tezi, Celal Bayar Üniversitesi, Manisa.

Banguoğlu, T. (2004). Türkçenin Grameri, Ankara: Türk Dil Kurumu Yayınları.

Baytop, T. (2007). Türkçe Bitki Adları Sözlüğü, Ankara: Türk Dil Kurumu Yayınları.

Belce, A. (1968). Manisa İli Yer Adları, Lisans Tezi, İstanbul Üniversitesi, İstanbul.

Bora, H. S. (1993). Allıance Israelite Universelle'in Osmanlı Yahudi Cemaatini Tarım Sektöründe Kalkındırma Çalışmaları ve İzmir Yakınlarında Kurulan Bir Çiftlik Okul: Or Yehuda, Çağdaş Türkiye Tarihi Araştırmaları Dergisi, 1(3): 387 - 400.

Câvid, İ. (2010). Aydın Vilâyet Sâlnâmesi (R.1307/H.1308), Ankara: Türk Tarih Kurumu Yayınları.

Çağlıyan, A. (2013). Harput ve Çevresinde Yer İsimlerine Coğrafi Bir Bakış, Geçmişten Geleceğe Harput Sempozyumu Bildirileri (23-25 Mayıs 2013), (ss.1073-1092), Elazığ: Firat Üniversitesi Harput Uygulama ve Araştırma Merkezi.

Çetin, S. (2013). 64 No'lu Manisa Şer'iyye Sicili, Yayınlanmamış Yüksek Lisans Tezi, Celal Bayar Üniversitesi, Manisa.

Devellioğlu, F. (2006). Osmanlıca - Türkçe Ansiklopedik Lugat, Ankara: Aydın Kitabevi.

Dilçin, C. (1983). Yeni Tarama Sözlüğü̈, Ankara: Türk Dil Kurumu Yayınları.

Doğan, M. (1981). Büyük Türkçe Sözlük, Ankara: Birlik Yayınları.

Doğanay, H. (2014). Türkiye Beşeri Coğrafyası, Ankara: Pegem Akademi Yayınları.

Emecen, M. F. (2007). Tarih İçinde Manisa, Manisa: Manisa Belediyesi Kültür Yayınları.

Emecen, M. F. (2013). XVI. Asırda Manisa Kazâsı, Ankara: Türk Tarih Kurumu Yayınları.

Eren, H. (2010). Yer Adlarımızın Dili, Ankara: Türk Dil Kurumu Yayınları.

Erkol, F. (2013). Afyonkarahisar İli Çay İlçesinin Mikrotoponimleri ve Dil İncelenmesi, Yayınlanmamış Yüksek Lisans Tezi, Afyon Kocatepe Üniversitesi, Afyonkarahisar.

Gökçen, İ. (1946). Saruhan'da Yürük ve Türkmenler, Manisa: Manisa Halkevi Yayınları.

Gökçen, İ. (1950). Tarihte Saruhan Köyleri, İstanbul: Berksoy Basımevi.

Göney, S. (1975). Büyük Menderes Bölgesi, İstanbul: İstanbul Üniversitesi Yayınları. 
Gülensoy, T. (2007). Türkiye Türkçesindeki Türkçe Sözcüklerin Köken Bilgisi Sözlüğü I-II, Ankara: Türk Dil Kurumu Yayınları.

Halaçoğlu, Y. (2011). Anadolu'da Aşiretler, Cemaatler, Oymaklar (1453 - 1650), İstanbul: Togan Yayıncilik.

Hüseynova, T. (2011). Azerbaycan Yer Adlarında Etnotoponimler, Yayımlanmamış Yüksek Lisans Tezi, İzmir: Ege Üniversitesi.

http://tdkterim.gov.tr/bts/ [Erişim Tarihleri: 06.08.2014, 14.08.2014, 21.09.2014, 23.09.2014].

İzbırak, R. (1964). Coğrafya Terimleri Sözlüğ̈̈, Ankara: Doğuş Matbaacılık.

İzdem, E. (1944). Dünkü-Bugünkü Akhisar, İstanbul: Ülkü Basımevi.

Kahraman, S. A. (2011). Günümüz Türkçesiyle Evliya Çelebi Seyahatnâmesi: Kütahya-Manisa-İzmir-

Antalya-Karaman-Adana-Halep-Şam-Kudüs-Mekke-Medine, İstanbul: Yapı Kredi Yayınları.

Karacan, N. (2014). Sinop İli Yerleşim Yeri Adları Üzerine Bir Dil İncelemesi. Yayınlanmamış Yüksek

Lisans Tezi, Afyon Kocatepe Üniversitesi, Afyonkarahisar.

Karaçetin, H. (1984). Antik Çağda Anadolu'da Tarihi Yer Adları, Türk Yer Adları Sempozyumu Bildirileri: (ss.219-223) 11-13 Eylül 1984-Ankara: Kültür ve Turizm Bakanlığı Yayınları.

Karaboran, H. (1984). Türkiye'de Mevki Adaları Üzerine Bir Araştırma, Türk Yer Adları

Sempozyumu Bildirileri, Seminer-Kongre Bildirileri Dizisi 17, Kültür ve Turizm Bakanlığı Milli

Folklor Araştırma Dairesi Yayın No: 60, 1984, (ss. 97-148), Ankara: Kültür ve Turizm Bakanlığ1

Milli Folklor Dairesi Yayınları,

Karahan, L. (2013). Türkçede Söz Dizimi (19. Baskı). Ankara: Akçağ Yayınları.

Karakuyu, M, Sarıusta, F. ve Yalçın, S. (2012). Kentleşme Sürecinde Akhisar. Akhisar: Akhisar

Belediyesi Kültür Yayınları.

Karakuyu, M, (2012). Mahalle Mahalle Akhisar, Akhisar: Akhisar Belediyesi Kültür Yayınları.

Karakuyu, M. (2012). Tarihi Coğrafyasıyla Akhisar, Akhisar: Akhisar Belediyesi Kültür Yayınları.

Koday, S. (2000). Geçmişte, Günümüzde ve Gelecekte Trakya. Coğrafya Meslek Haftaları Serisi: 2 (28. Coğrafya Meslek Haftas1), 10-12 Haziran 1998, İstanbul, Türkiye.

Koday, S, Kaya, G, Akbaş, F. (2016). Salihli İlçesinde Köy Adlarında Coğrafyanın Etkisi, Atatürk Üniversitesi Sosyal Bilimler Enstitüsü Dergisi, 20 (2): 559-582.

Koday, S. ve Aydın, T (2016). Elmalı' da (Antalya) Geçmişten Günümüze Yerleşme Adları Üzerine Bir İnceleme, Tücaum Uluslararası Coğrafya Sempozyumu, 13-14 Ekim 2016, Ankara, Türkiye.

Koday S., Akbaş F., (2016). Erzincan İli Köy Yerleşmelerinde Topoğrafya ve Bakı Koşullarının Toponimik Açıdan İncelenmesi, 14. Uluslararası Türk Dünyası Sosyal Bilimler Kongresi, İstanbul, Türkiye.

Koday, S. (1998). Trakya da Köy Adlarında Coğrafyanın Etkisi, Türk Coğrafya Kurumu 28. Coğrafya Meslek Haftası: Geçmişte, Günümüzde ve Gelecekte Trakya, 10-11-12 Haziran 1998, Türkiye. 
Koday, Z, Akbaş, F, ve Kaya, G. (2017). Akhisar Büyükşehir İlçesinin İdari Coğrafya Analizi, Atatürk Üniversitesi Sosyal Bilimler Enstitüsü Dergisi, 21 (2): 443-455.

Koday, Z. (2003). Arhavi Çayı Havzası'nın Coğrafyası, Erzurum: Atatürk Üniversitesi Yayınları.

Koday, Z. (2014). Fındıklı İlçesinin Coğrafyası, Erzurum: Atatürk Üniversitesi Yayınları.

İçişleri Bakanlığı. (1968). Köylerimiz, Ankara: Içişleri Bakanlığı İller İdaresi Genel Müdürlüğü

Yayınları

Kurgun, L. (2002). Denizli İli Yer Adları, Yayınlanmamış Doktora Tezi, Pamukkale Üniversitesi,

Denizli.

Müderrisoğlu, M. E. (1956). Akhisarlı Türk Büyükleri ve Eserleri, İzmir: Piyasa Matbaası.

Nagata, Y. (1979). 16. Yüzyılda Manisa Köyleri: 1531 Tarihli Saruhan Sancağına Ait Bir Tahrir

Defterini İnceleme Denemesi. Tarih Dergisi, 32, 731-758.

Nagata, Y. (1997). Tarihte Âyânlar Karaosmanoğulları Üzerinde Bir İnceleme, Ankara: Türk Tarih

Kurumu Yayınları.

Özkılınç, A., Coşkun, A., Karazeybek, M., Sivridağ, A. ve Yüzbaşığlu, M. (1995). 166 Numaralı Muhâsebe-i Vilâyet-i Anadolu Defteri (937/1530), (Defter-i Hâkâni Dizisi: II). Ankara: Başbakanlık

Devlet Arşivleri Genel Müdürlüğü.

Resmî Gazete, 11 Nisan 1989, Sayı 20136.

Resmî Gazete, 16 Şubat 1945, Sayı 5933.

Resmî Gazete, 2 Ocak 1951, Say1 7697.

Resmî Gazete, 21 Haziran 1934, Sayı 2733.

Resmî Gazete, 27 Şubat 1947, Sayı 6543.

Satış, B. (1994). İlkçağdan Günümüze Akhisar, İzmir: Akhisar Sağlık Eğitim Kültür Vakfı Yayınları.

Sezen, T. (2006). Osmanlı Yer Adları (Alfabetik Sırayla), Ankara: Başbakanlık Devlet Arşivleri Genel Müdürlüğü.

Son Teşkilatı Mülkiyede Köylerimizin Adları. (1928). İstanbul: Hilâl Matbaası.

Şahin, İ. (2007). Türkçe Yer Adlarının Yapısı Üzerine. Türkiyat Araştırmaları Enstitüsü Dergisi, Sayı 32: 1-14.

Şahin, İ. (2011). Yeradı Bilim Çalışmalarında Mikrotoponiminin Yeri, Önemi ve Araştırma Yöntemi: Tırnak Köyü (İçel / Gülnar) Örneği. Turkısh Studies, 1807 - 1830.

Şahin, İ. (2013). Türkiye Yeradbiliminde Terim ve Tür Sınıflandırması Sorunları. Avrasya Terimler Dergisi, 1 (1): 46 - 58.

Şahin, İ. (2014). Toponimi Çalışmalarında Leksikosemantik Sınıflandırma Ne Şekilde Olmalıdır. 7. Uluslararası Dünya Dili Türkçe Sempozyumu, 16- 18 Ekim, Elazığ.

Şaşmaz, M. (2014). Türkiye'nin İdari Taksimatı (1920-2013), Ankara: Türk Tarih Kurumu Yayınları, $X I$. 
Talaysüm, B. (1965). Akhisar İlçesi Monoğrafyası, Lisans Tezi, İstanbul Üniversitesi, İstanbul.

Tuncel, H. (2000). Türkiye'de İsmi Değiştirilen Köyler, Fırat Üniversitesi Sosyal Bilimler Dergisi, 10 (2): 23-34.

Tuncel, M, (1995), Eskişehir, Türkiye Diyanet Vakfı İslâm Ansiklopedisi, C: 11, İstanbul: Türkiye Diyanet Vakfı Yayınları.

Türkay, C, (1979). Basbakanlık Arsivi Belgelerine Göre Osmanlı İmparatorlugu'nda Oymak, Asiret ve Cemâatlar, İstanbul: Garanti Matbaası,

İç İşleri Bakanlığı (1981). Köylerimiz (1981), Ankara: İç İşleri Bakanlığı İller İdaresi Genel Müdürlügü Yayınları.

Türkay, C. (2001). Başbakanlık Arşiv Belgelerine Göre Osmanlı İmparatorluğunda Oymak, Aşîret ve Cemaatlar, İstanbul: İşaret Yayınları.

Türkçe Sözlük. (2005). (10. Bask1). Ankara: Türk Dil Kurumu Yayınları.

Türk Dil Kurumu. (1965, 1968, 1969, 1972, 1974, 1975, 1977, 1978, 1979). Türkiye'de Halk Ağzından

Derleme Sözlüğü, Ankara: Türk Dil Kurumu Yayınları.

Umar, B. (1993). Türkiye'deki Tarihsel Adlar, İstanbul: İnkılâp Kitabevi.

Yaşar, O ve Yaşar, F, Ö. (2010). Ayvacık, Bayramiç, Çan, Ezine ve Yenice (Çanakkale İli) İlçelerinde Köy Adlarının Kaynakları, Uluslararası Sosyal Araştırmalar Dergisi, 3 (11), 599-611.

Yavuz, S. ve Şenel, M. (2013). Yer Adları (Toponim) Terimleri Sözlüğü. Turkish Studies, 2239-2254. 